\title{
Comparison of Structure and Tasks of Forensic Psychiatry in Iran and European Countries
}

\author{
Seyed Mehdi Saberi ${ }^{*}$, Sayed Mahdi Marashi², Elham Borji ${ }^{3}$, Armindokht Ahmadi ${ }^{4}$, Mehdi Forouzesh \\ 1. MD, Psychiatrist, Legal Medicine Research Center, Legal Medicine Organization of Iran, Tehran, Iran \\ 2. MD, Assistant Professor, Forensic Medicine and Clinical Toxicology, Shiraz University of Medical Sci- \\ ences, Shiraz, Iran \\ 3. MD, Psychiatrist, Department of Medical Commissions, Legal Medicine Organization of Iran, Tehran, \\ Iran \\ 4. MA in Psychometrics, Legal Medicine Research Center, Legal Medicine Organization of Iran, Tehran,Iran \\ 5. MD, Assistant Professor, Legal Medicine Research Center, Legal Medicine Organization, Tehran, Iran
}

\section{Article Info \\ Received: $\quad$ 09 June 2016 Accepted: $\quad 29$ June 2017} Published Online 03 Dec 2017

DOI: $10.30699 /$ epub.sjfm.23.3.174

Original Article

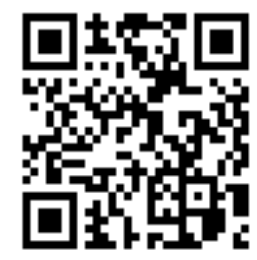

\section{Abstract}

Background: The purpose of the study was to compare forensic psychiatric setting in Iran with European countries.

Materials and Methods: First a qualitative study (experience expression) was done, interviewing the forensic psychiatrics. Then to understand the sections of forensic psychiatry department, articles, scientific references and the relevant sites were reviewed. Their work was analyzed using emails and phone calls. Recording data forms that included different services, the way they worked and human resources' potential in forensic psychiatric system in any of the chosen countries were filled accordingly.

Findings: In most studied European countries, the examination method, treatment, rehabilitation and post discharge care are the same. Observing the patient's behavior and social interactions is one of the most important diagnostic tools. In Europe, forensic psychiatric activities' focus is on criminal matters: risk assessment, treatment and rehabilitation of criminal patients. The more executive diagnostic facilities of forensic psychiatry and secure mental hospitals with special deparments are important factors that make significant difference.

Conclusion:Despite the differences that exist in European departments of forensic psychiatry's activities, similarities are observed in factors such as mental patients' examination method, diagnostic and treatment facilities, preparing a psychiatric report for the court. The activity of Iranian's system isn't functional enough in comparison to European system, due to factors like lack of standardized and secure diagnostic facilities, and limited access to criminal patients and courts. To improve the system, our country should consider some actions such as: establishment of standardized sections in prisons and psychological hospitals, longterm program to establish special hospitals, using common and standard tools of risk assessment and establishment of follow up clinics and nursing (guardian) houses for post discharge care of criminal patients.

Keywords: Forensic Psychiatry; Diagnostic Facilities; Secure Mental Hospital; Europe; Iran \footnotetext{
$\begin{array}{ll}\text { Corresponding Information } & \text { Dr. Seyed Mehdi Saberi, M.D., Psychiatrist, Legal Medicine Research Center, Legal Medicine Organization of Iran, } \\ \text { Tehran, Iran. Email: saberi_md@yahoo.com } & \text { Tel:02155162540 }\end{array}$

Copyright (C) 2017, Ir J Forensic Med. This is an open-access article distributed under the terms of the Creative Commons Attribution-noncommercial 4.0 International License which permits copy and redistribute the material just in noncommercial usages, provided the original work is properly cited.

How to Cite This Article:

Saberi M, Marashi M, Borji E, Ahmadi A, Forouzesh M. Comparison of Structure and Tasks of Forensic Psychiatry in Iran and European Countries. Ir J Forensic Med. 2017; 23 (3) :174-189
} 


\section{مقايسةٔ ساختار و محدودهُ وظايف روانيزشكى قانونى ايران و كشورهاى ارويايى}

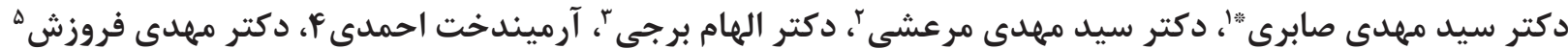

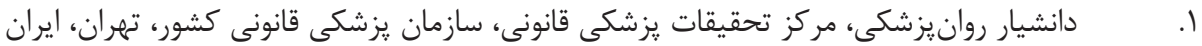

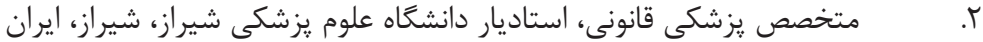

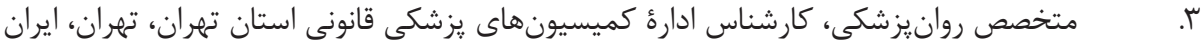

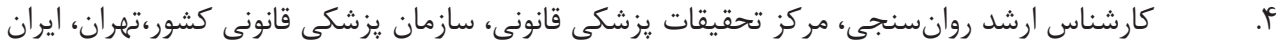

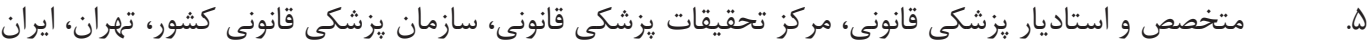

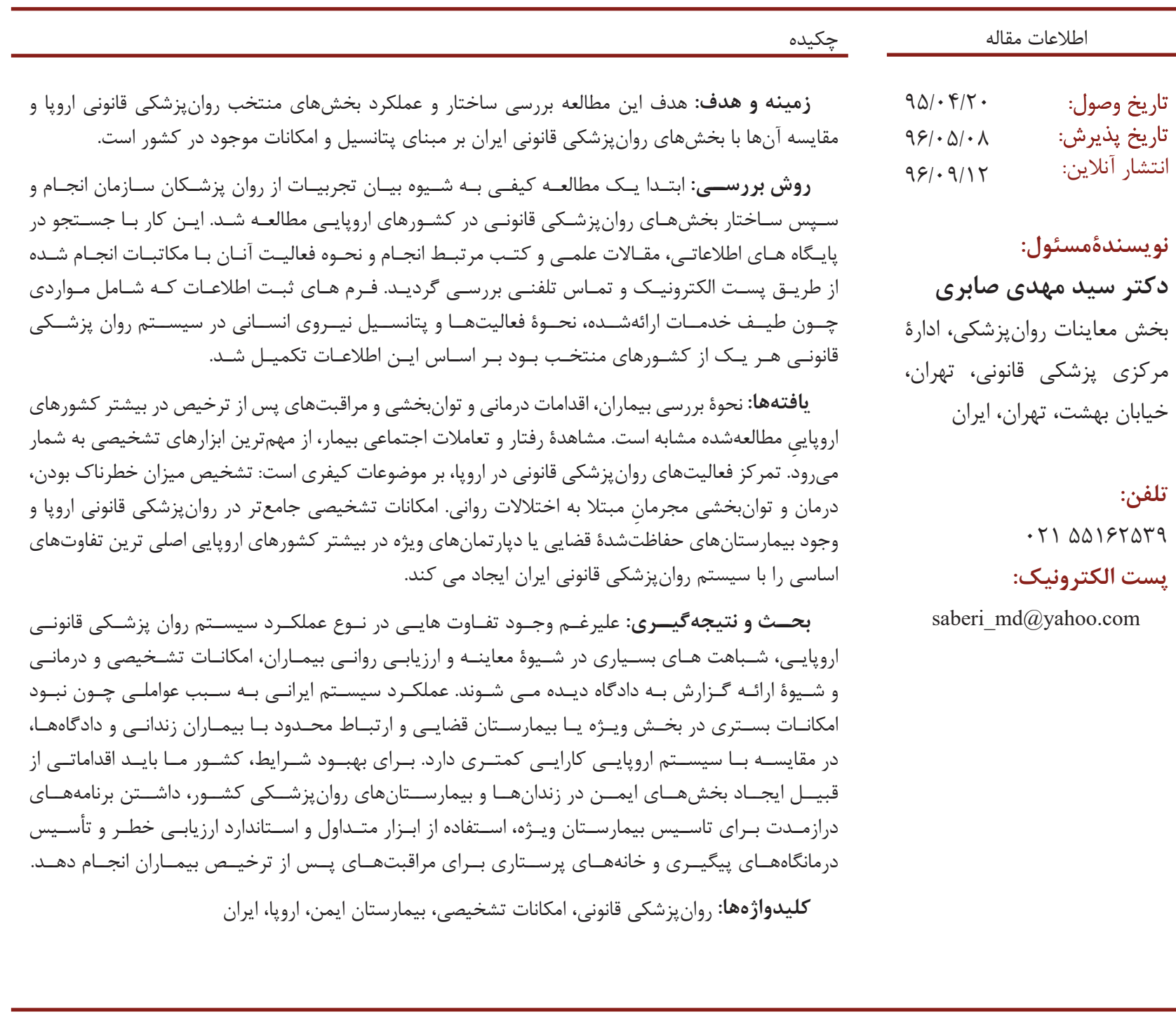




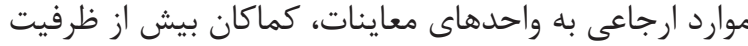

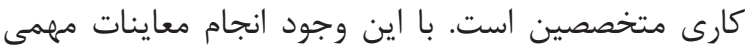

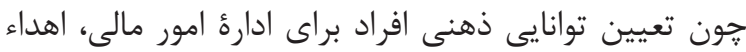

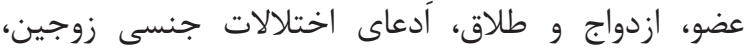

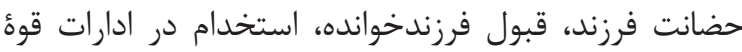

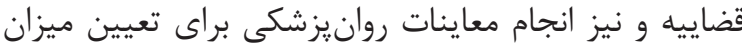

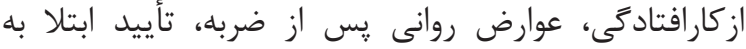

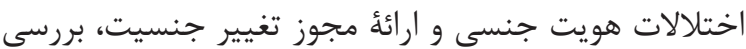

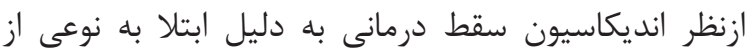

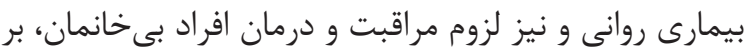

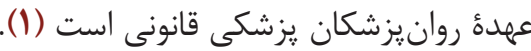

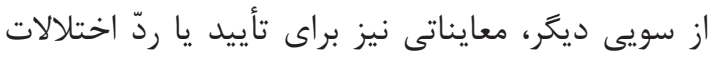

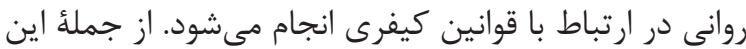

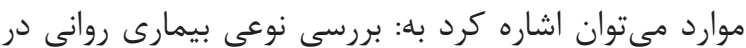

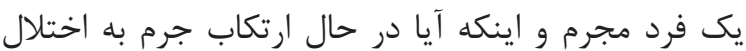

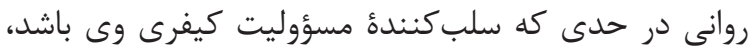

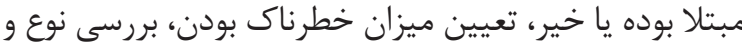

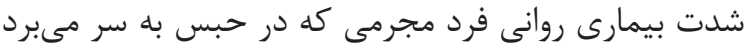

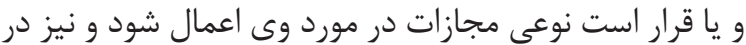

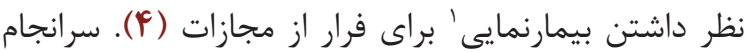

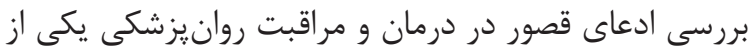

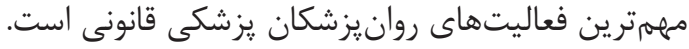

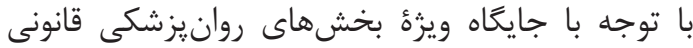

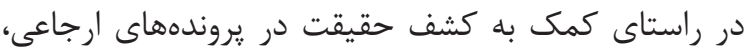

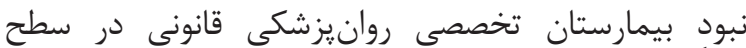

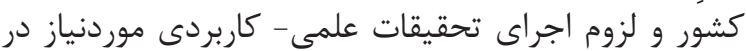

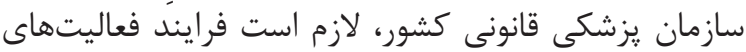

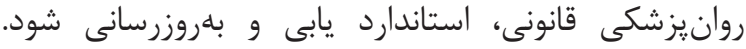

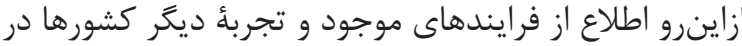

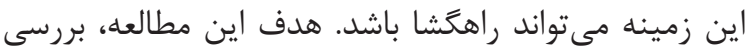

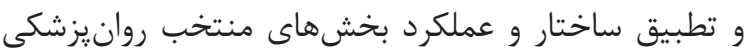

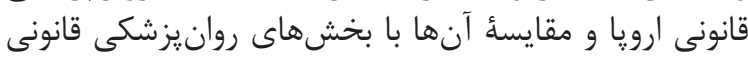

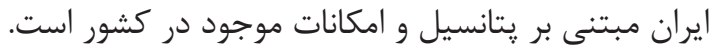

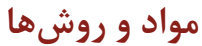

اين يزوهش بر مبناى روش كزارشى، بدون تأكيد بر تارئ

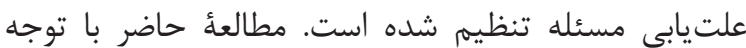

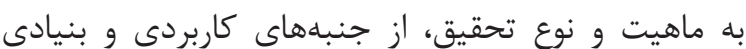

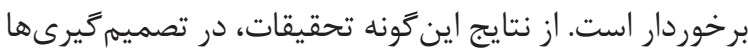

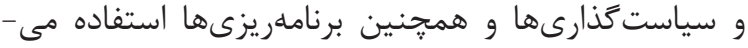

امروزه سازمان يزشكى قانونى با در اختيار داشتن

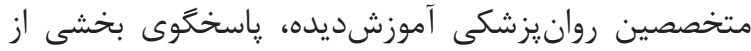

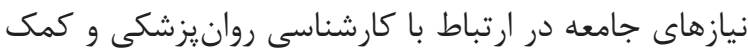

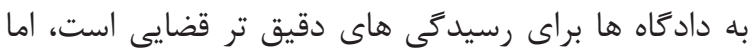

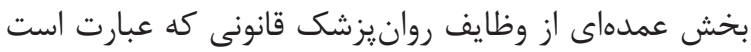

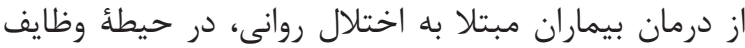

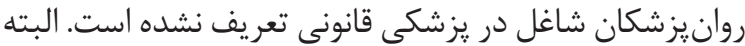

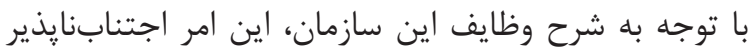

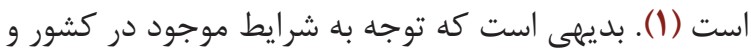

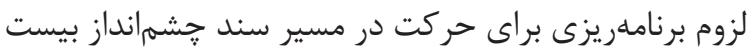

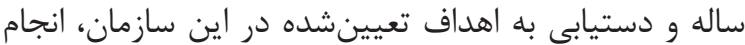

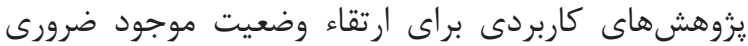

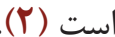

سازمان يزشكى قانونى كشور با هدف ارتقاء همهجانبو

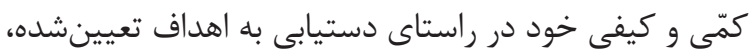

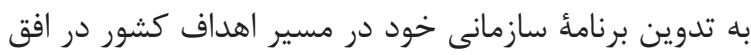

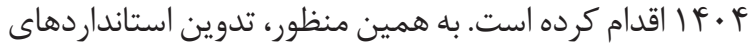

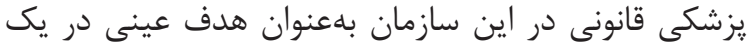

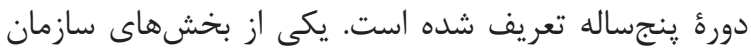

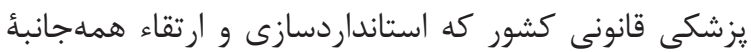

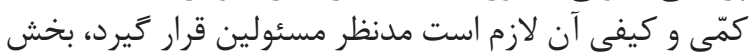

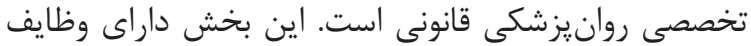

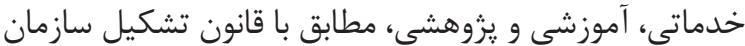

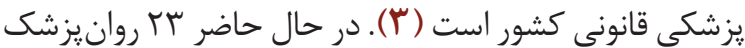

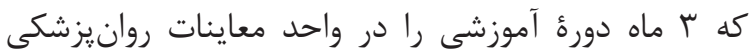

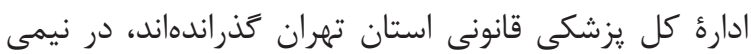

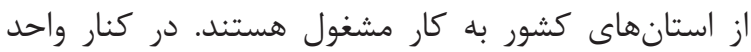

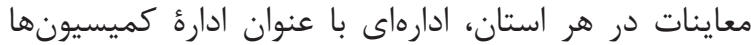

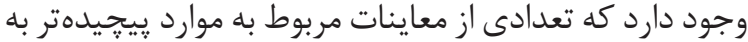

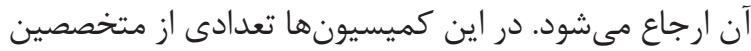

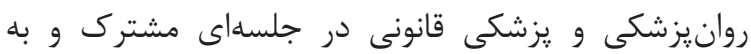

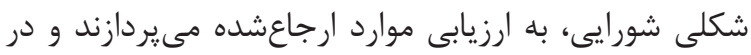

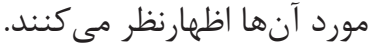

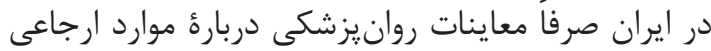

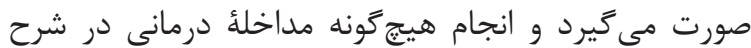

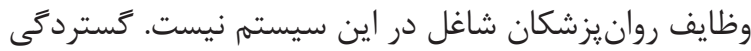

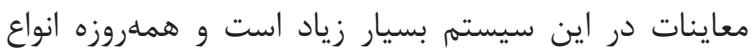

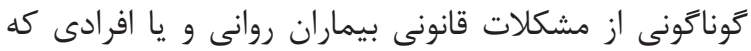

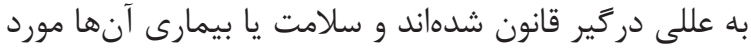

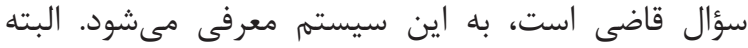

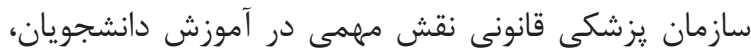

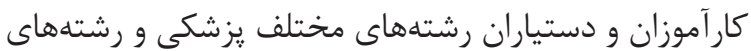

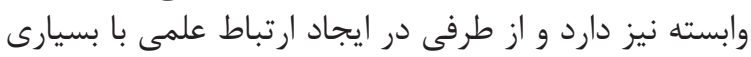

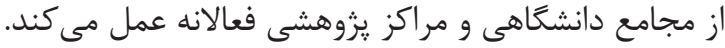
واحدهاى معاينات روانيزشكى قانونى مستقر در ادارات كل استان داراى فضاى فيزيكى محدودى هستند و و تعداد دان دان 


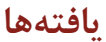

\section{ساختار روانيزشكى قانونى در ايران}

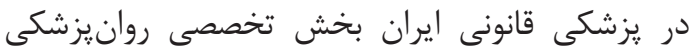

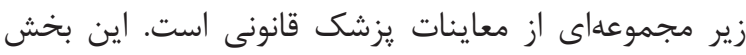

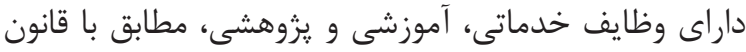

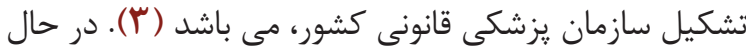

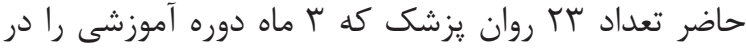

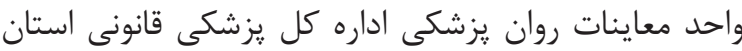

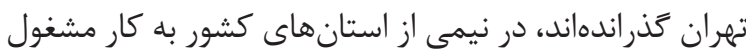

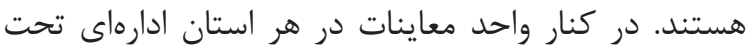

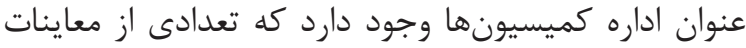

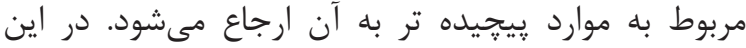

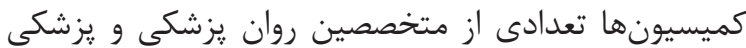

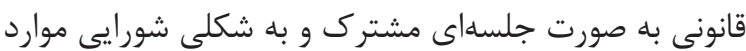

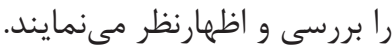

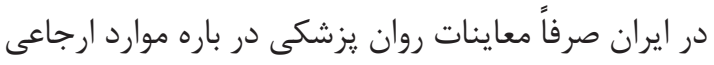

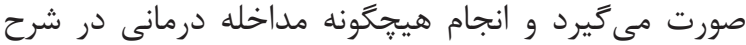

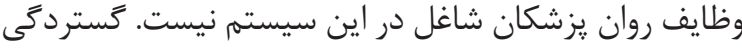

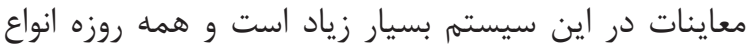

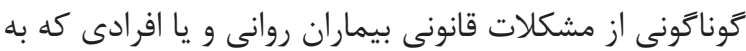

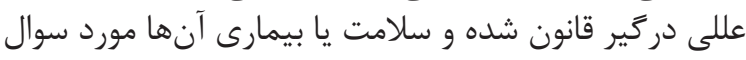

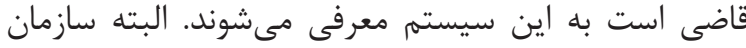

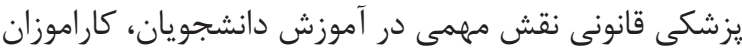

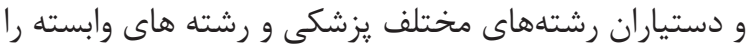

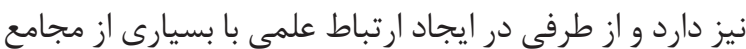

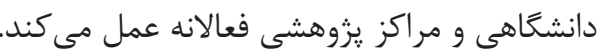

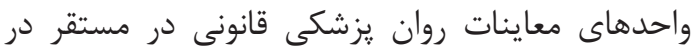

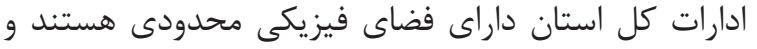

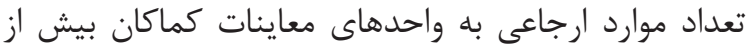

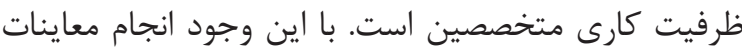

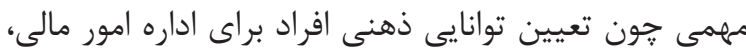

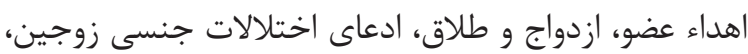

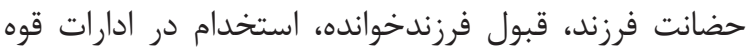

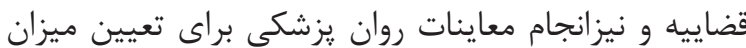

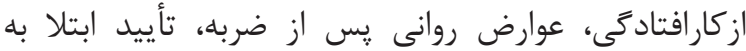

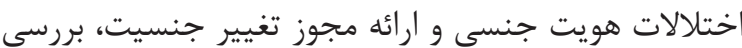

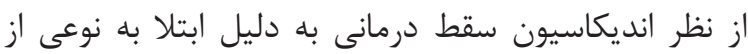

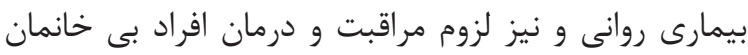
برعهله روان يزشكان يزشكى قانونى است.

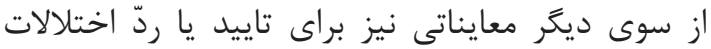

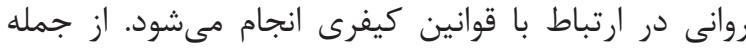

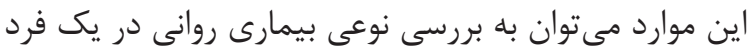

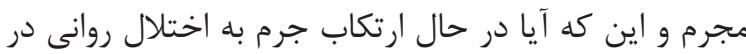

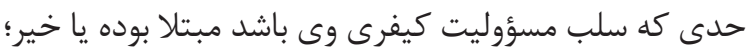

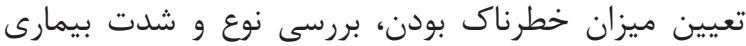

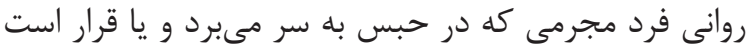

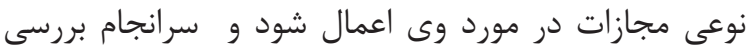

با توجه به اينكه براى ييش بينى و برآورد وضع آتى كزئ

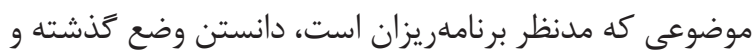

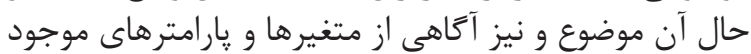

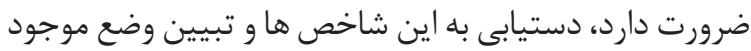

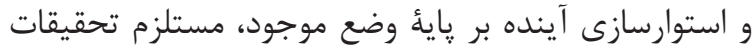

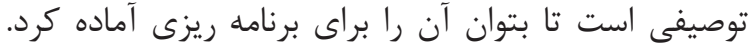

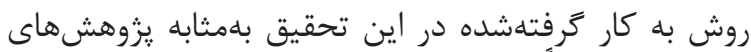

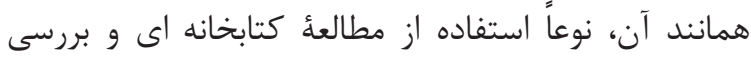

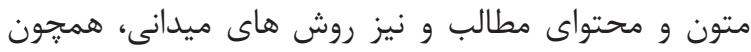
يرسش نامه، مصاحبه و مشاهده بون بوده است.

\section{مراحل انجام تحقيق}

اين يزوهش با توجه با ماهيت كار، در مراحل جداءأنه

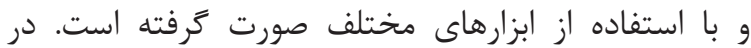

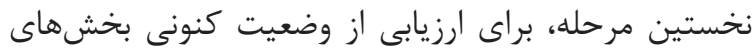
روانيزشكى قانونى در كشور، يك مطالعهأ كيفى به شئ شيؤ بئ بيان

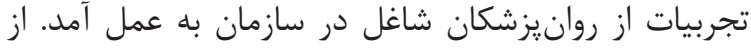

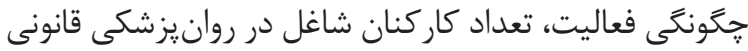

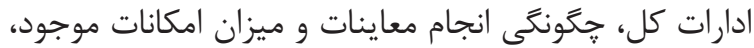

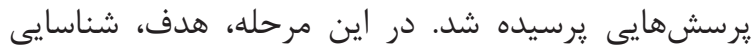

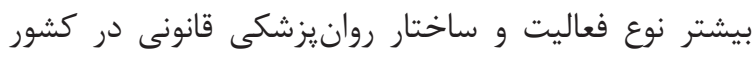

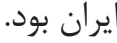

در مرحله دوم، براى دستيابى به ساختار بخشهاى درئي

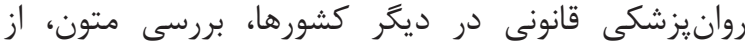

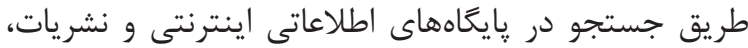

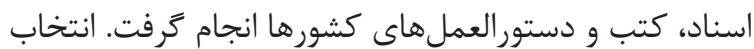

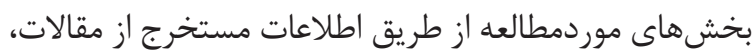

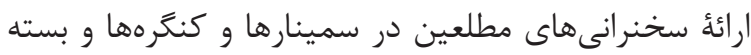

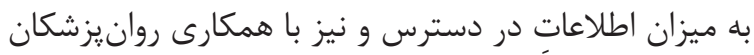

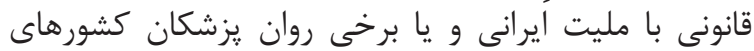

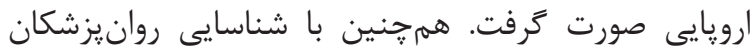

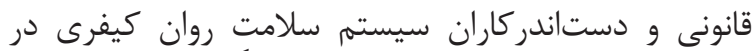

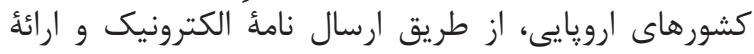

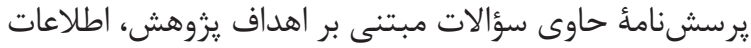

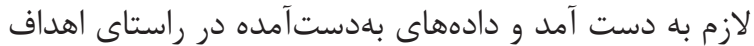

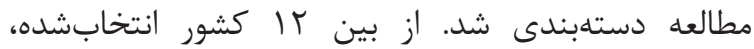

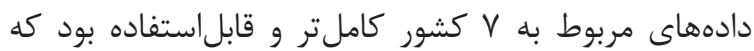
مبناى مقايسٔ يزوهش پيش رو رو قرار كرفت

در مرحلة سوم مطالعه كه با هدف كمك بارئ به ارائه

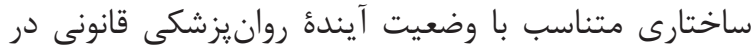

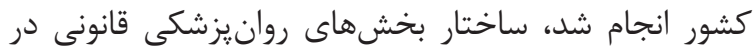

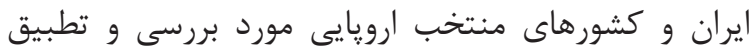

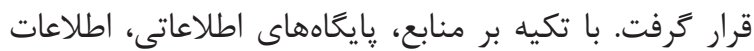

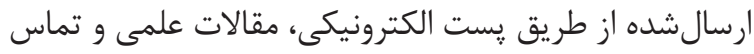

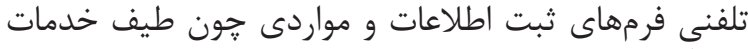

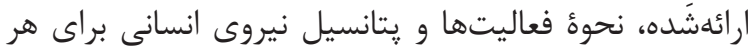
يك از بخشهاى منتخب تكميل شد. فيتها 


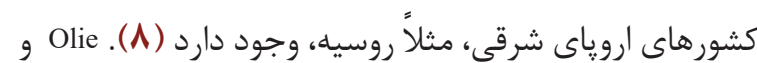

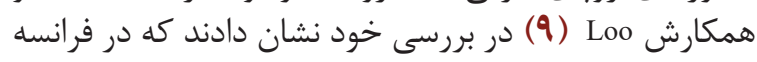

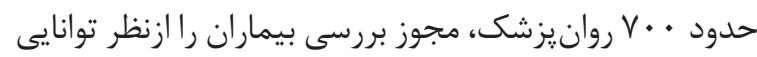

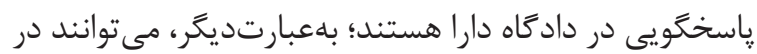

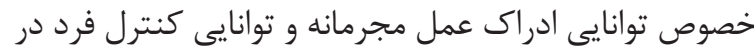
هنگام وقوع جرم اظهارنظر كنند.

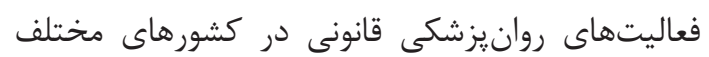

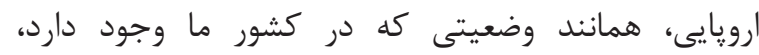

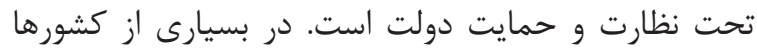

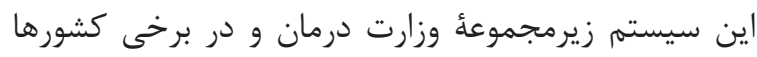

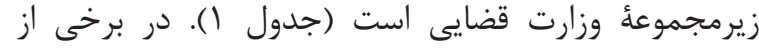

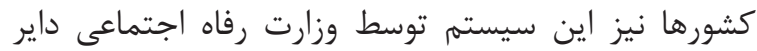

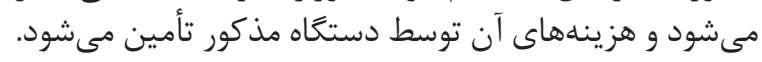

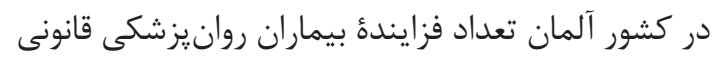

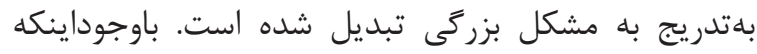

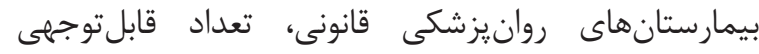

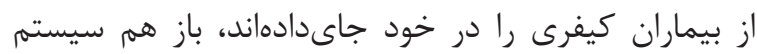

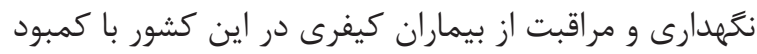

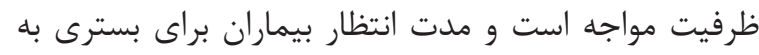

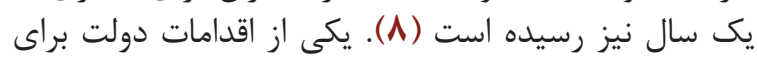

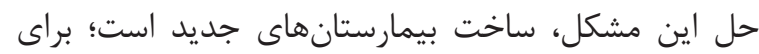

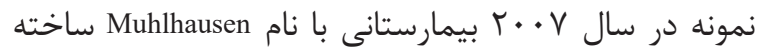

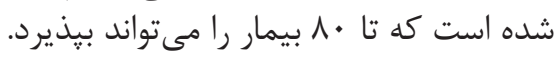

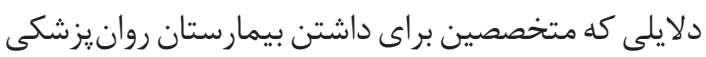

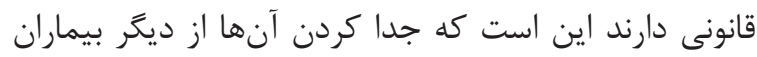

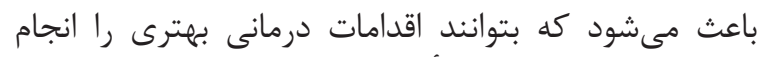

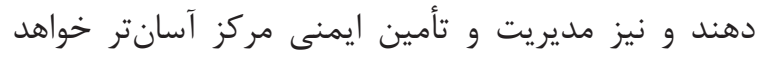

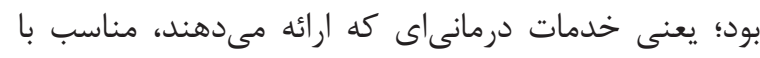

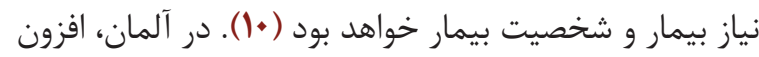

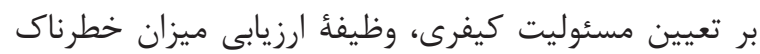

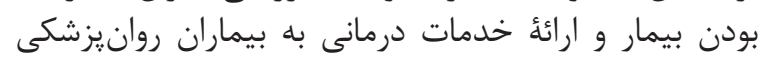

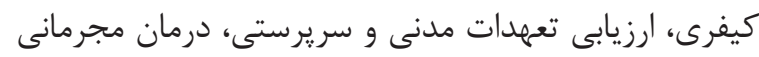

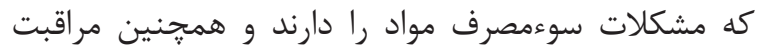

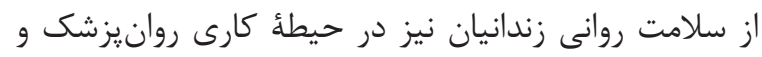
روانشناس قانونى است (•(1)، (1).

در انكلستان بيشتر روانيزشكان قانونى در سيستم

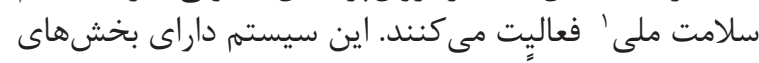

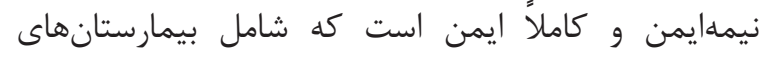
Rampton و Broadmoor، Ashworth فعاليتهاى روانيزشكى قانونى، در بيمارستانهاى سه كانه،

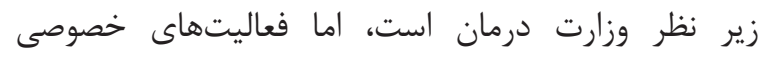

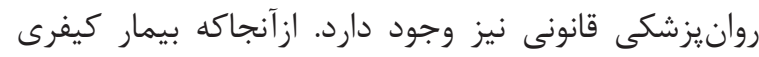

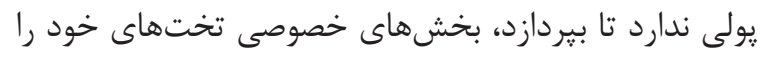

ادعاى قصور در درمان و مراقبت روان يزشكى اشاره كرد.

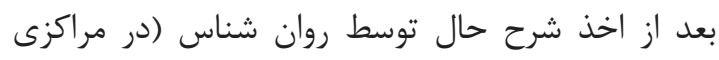

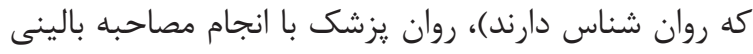

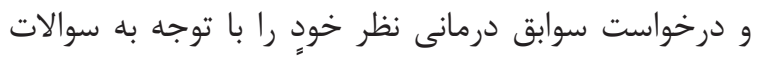

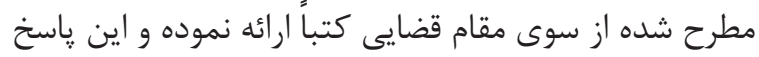

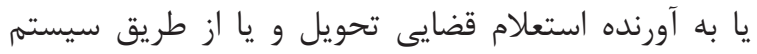

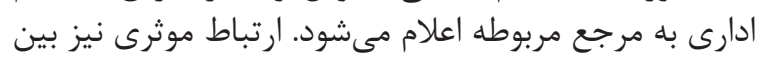

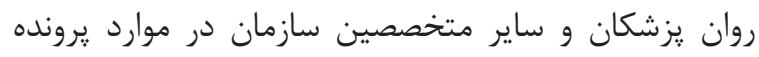

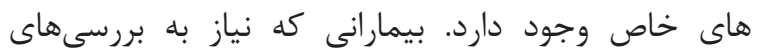

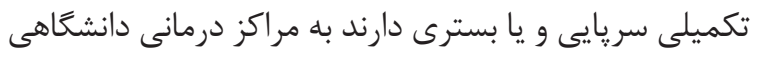

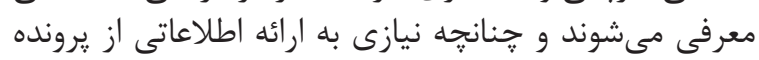

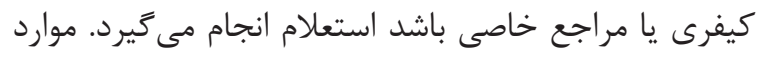

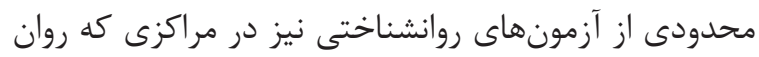

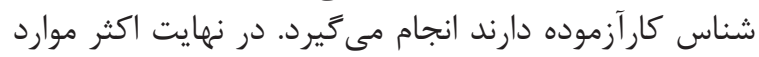

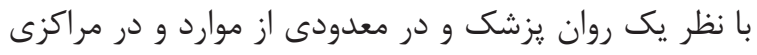

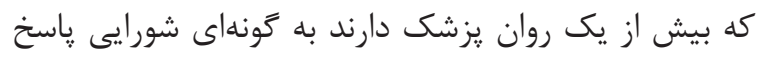

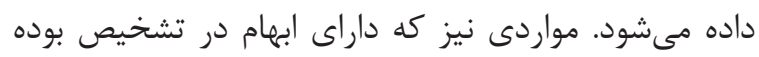

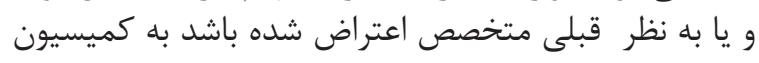

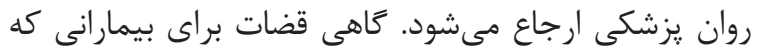

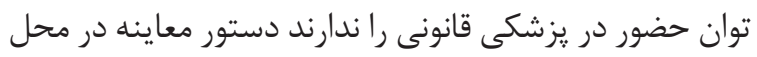

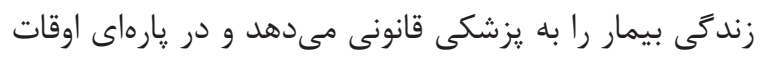

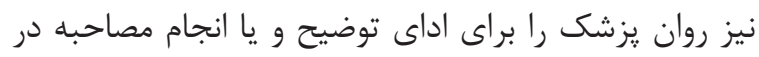

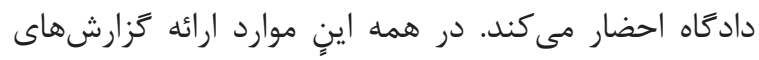

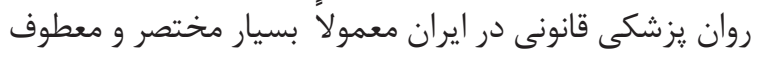
به سوال مطرح شده از سوى مقام قضايى است.

\section{ساختار روانيزشكى قانونى در ارويا}

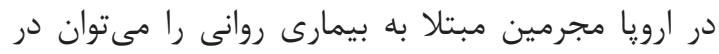

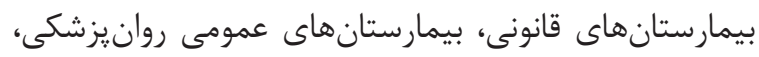

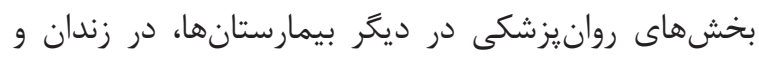

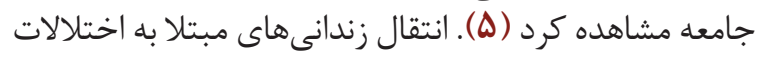

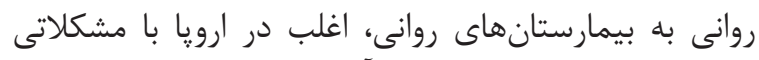

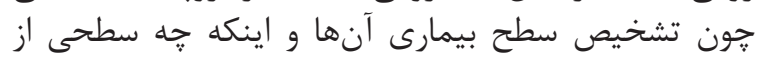

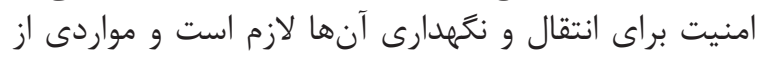

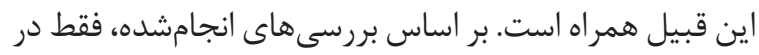

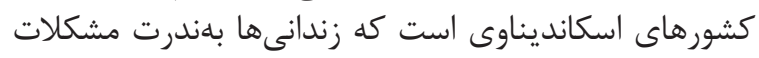

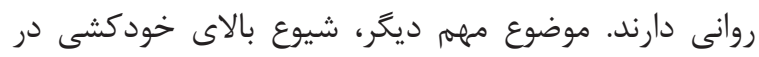

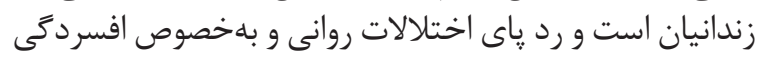

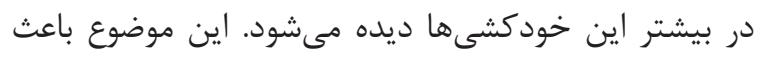

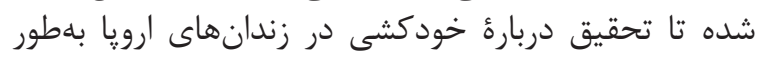

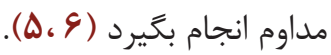

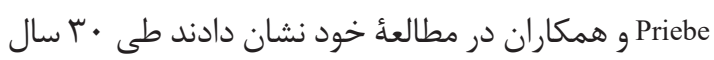

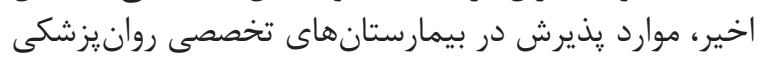

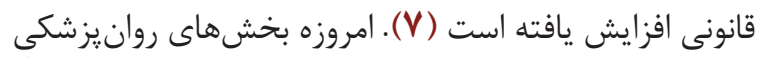

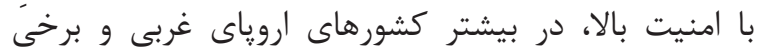


جدول شمارهُ ا. نوع و تعداد مراكز روانيزشكى قانونى، امكانات درمانى و سيستم ناظر در ايران و ارويا

\begin{tabular}{|c|c|c|c|c|c|c|}
\hline نظارت كنتنده & تقر كاركنان & امكانات درمانى & نوع فعاليت & تعداكز & نوع مراكز & 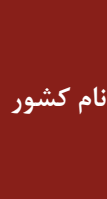 \\
\hline 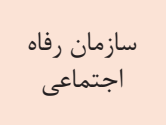 & 4. & كارودردانى، & مراقبت، درمان، توانبخشى و يِيخيرى & 19 & كلينيك پِيخيرى و خانههاى سريرستى & آلمان \\
\hline وزارت قضايى & V. & كارودردمانى، & مراقبت، درمان و پِيخيرى & r & بيمارستان و خانههاى يرستارى & سوئد \\
\hline 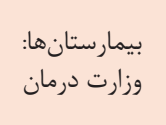 & $19 \cdots$ & كارودرمانى، & مراقبت، درمان، توانبخشى و يِيخيرى & $r$ & كلينيك هاى خصوصى، بيمارستان، & 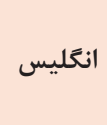 \\
\hline وزارت بهان وازمت و وان & $\wedge$. & كارودردانى، & مراقبت، درمان، توانبخشى و يِيَيرى & 1 & كركز جامع شامل بيمارستان و وران & روسيه \\
\hline وزارت قضايى & $\Lambda \Delta$ & كارودردانى، & مراقبت و درمان & $\Delta$ & بيمارستان و بخش & 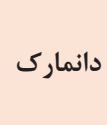 \\
\hline 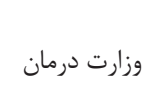 & 4. & دارودرمانى، & ارجاع براى درمان و مراقبت و يِيخيرى در & r & ارجاع بيار تمان و كلينيك، & 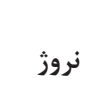 \\
\hline وزارت قضايى & 90. & كارودردانى، & درمان و يِيَيرى & 10 & و ولينيك ديارتمانيرى & 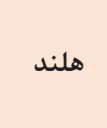 \\
\hline قوه قضاييه & f. & 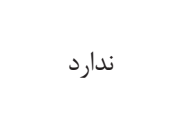 & 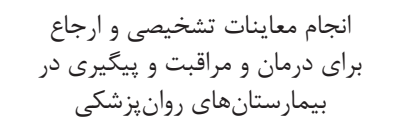 & 10 & واحدهاى معاينات سريايى و & 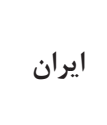 \\
\hline
\end{tabular}

نيست و هر فرد متخصص در روانيزشكى عمومى مئى دواند

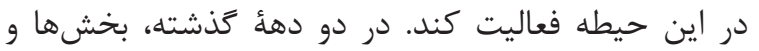

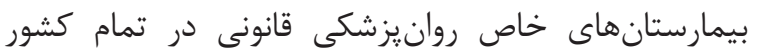

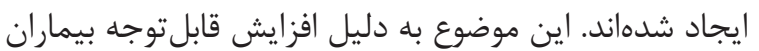

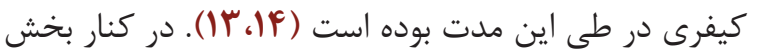

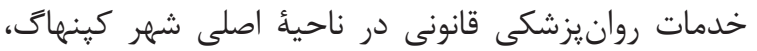

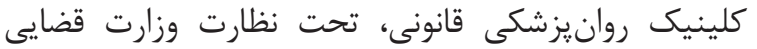

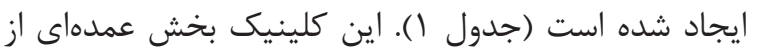

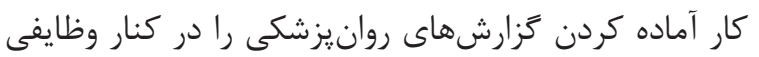

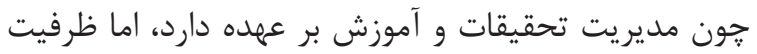

$$
\text { درمانى يايينى دارد. }
$$

در سوئد، سيستم ارزيابى روانيزشكى قانونى در سال

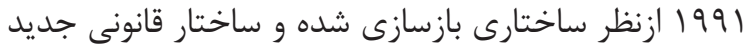

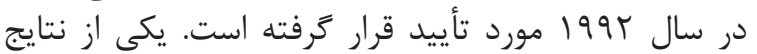

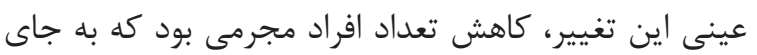

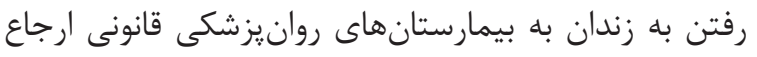

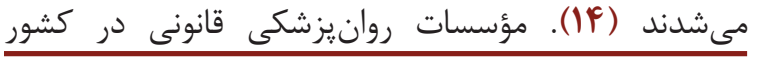

1- National Health Service

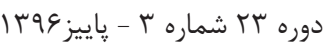

منحصراً به سيستم خدمات سلامت ملى مىفروشند (II) (I) در

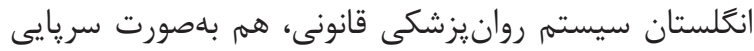

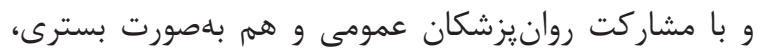

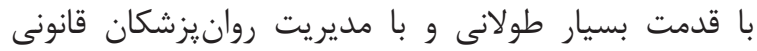

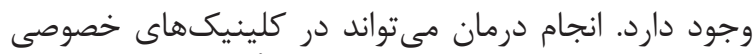

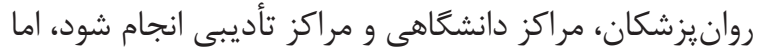

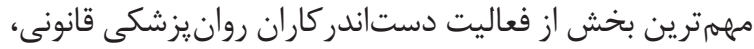

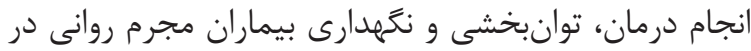

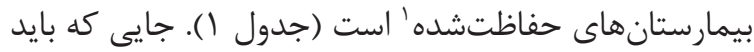

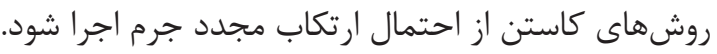
در كشور دانمارك، روانيزشكى قانونى همانند سيستم

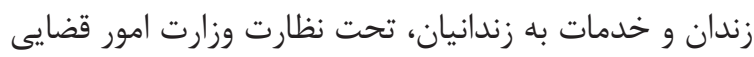

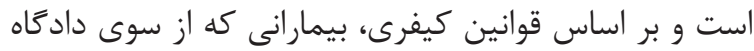

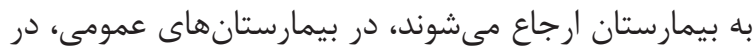

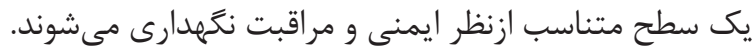
در اين كشور روانيزشكى قانونى يكى تخصص مئس جداعانه 
درمان و مراقبت توسط •r خدماتدهنده مراقبت استاندارد

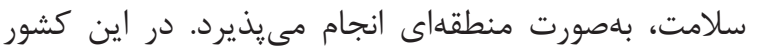

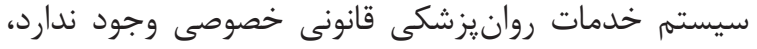

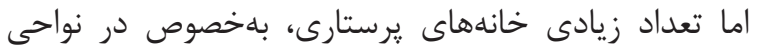

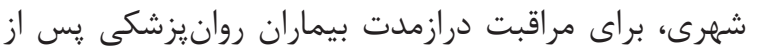

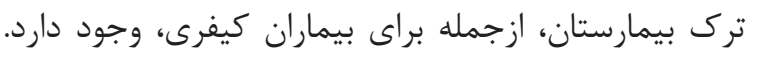

سوئد، اعم از كاركنان تيم درمان و كادر مراقبت، همانداند

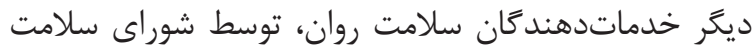

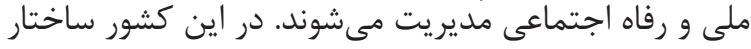

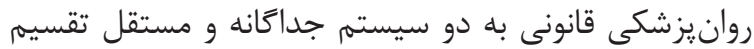

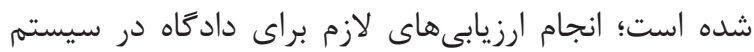

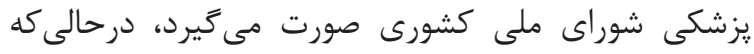

جدول شماره r. كاركنان تخصصى شاغل در مراكز روانيزشكى قانونى ايران و ارويا

\begin{tabular}{|c|c|c|c|c|c|c|c|c|c|}
\hline مربى ورزش & برستار & حقوقدان & آموزكار & اجتماعى & يزشك & كار درمانتر & روان شناس & روان بزشك & \\
\hline+ & + & + & + & + & - & + & + & + & آلمان \\
\hline+ & + & + & + & + & + & + & + & + & سوئد \\
\hline+ & + & + & + & + & + & + & + & + & انغَليس \\
\hline+ & + & + & + & + & + & + & + & + & روسيه \\
\hline- & + & + & - & + & + & + & + & + & دانماركى \\
\hline- & - & - & - & - & - & - & + & + & نروز \\
\hline+ & + & - & - & + & - & + & + & + & هلند \\
\hline- & - & - & - & - & - & - & + & + & ايران \\
\hline
\end{tabular}

كه در سال بr 9 ا زندانيان مجرم را قذيرفته و سال ها بيماران

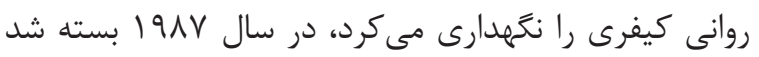

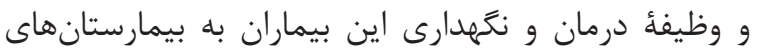

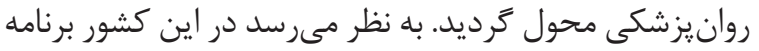

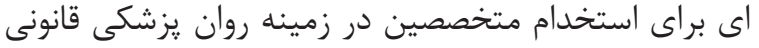

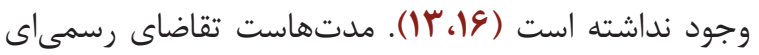

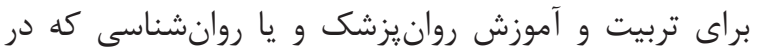

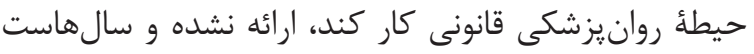

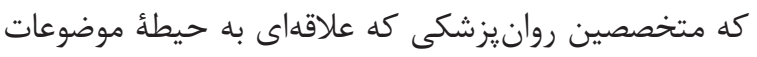

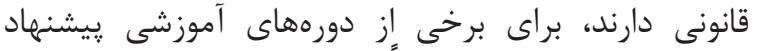

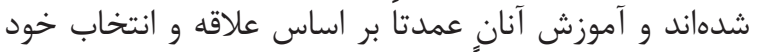

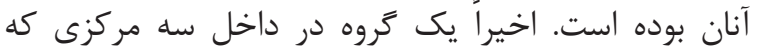

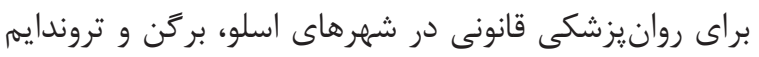

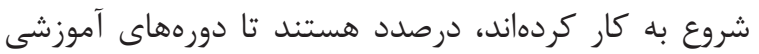

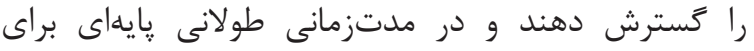

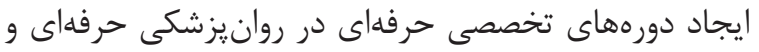

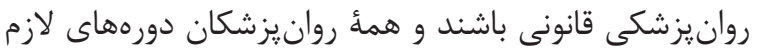
در اين زمينه را كذرانده باشند.

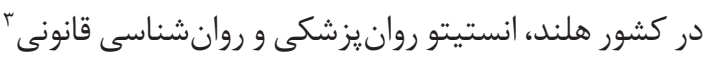

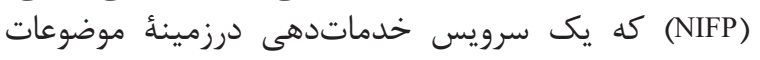

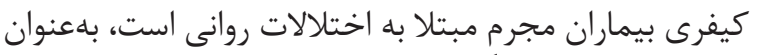

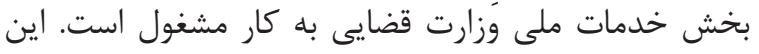

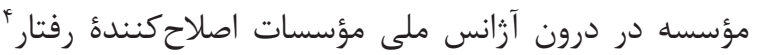

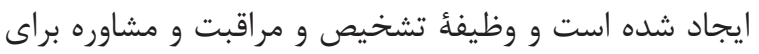

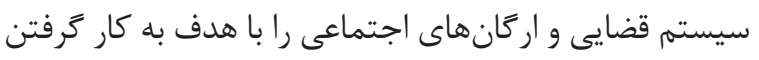

روانيزشكان قانونى استخدام رسمى دولت هستند و وظيفهُ اصلى آنان كار كردن براى اين سيسته است.

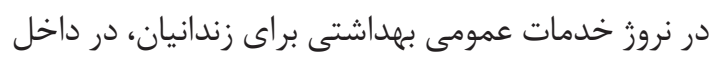

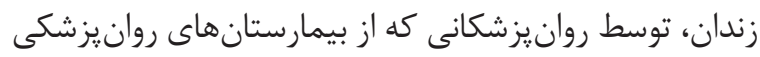

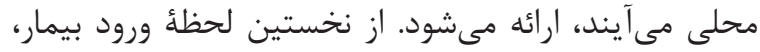

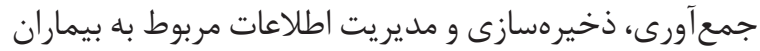

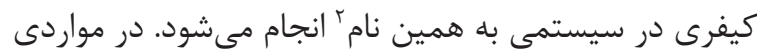

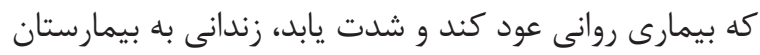

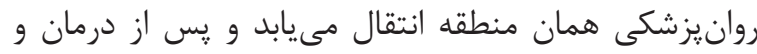

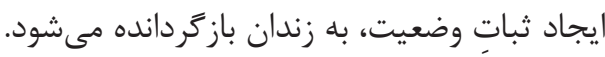
هيئت يزشكى قانونى اين كشور بّ كه اختصاراً

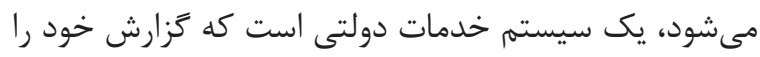

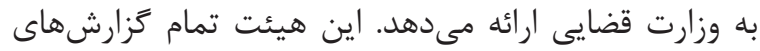

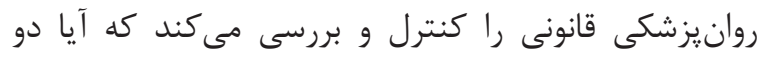

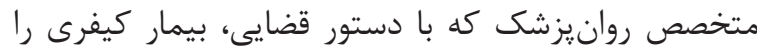

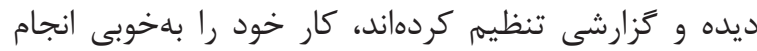

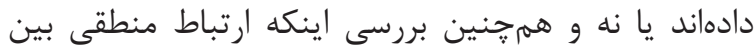

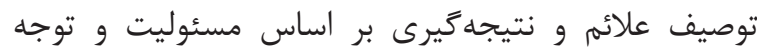

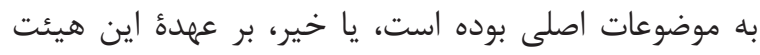

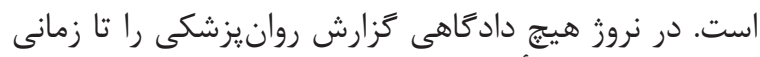

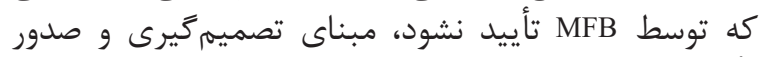
رأى قرار نمىدهد. هيج مؤسسأ دولتى عمومى (بيمارستان تصني

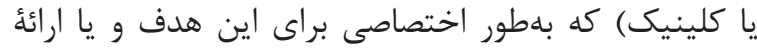

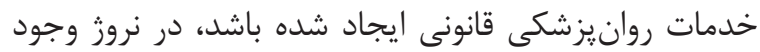

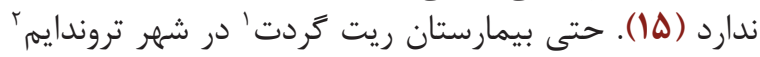


به نام Sikringen، با ظرفيت · r تخت، ه زندان بسته با ظرفيت

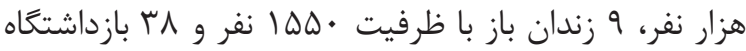

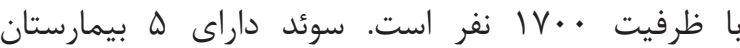

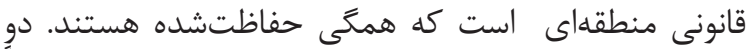

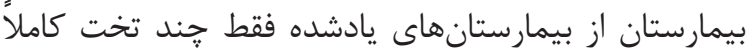

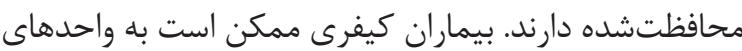

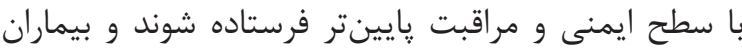

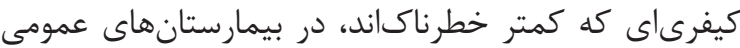
يذيرش مىشوند و تحت مراقبت قرار مى گئيرند.

در انگلستان بيمارستانهاى حفاظتشدهُ برادمور، اشورث

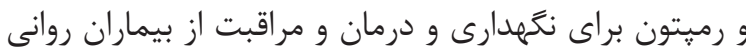

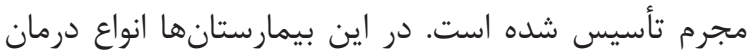

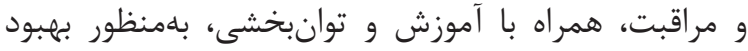

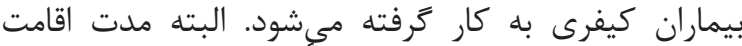

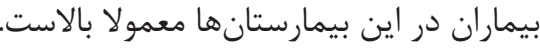

در روسيه بخش روانيزشكى قانونى مركز Serbsky با ب إن

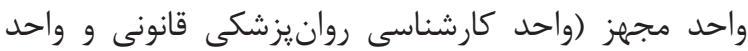

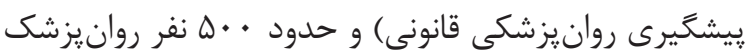

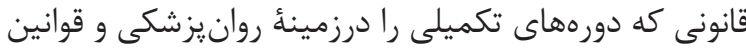

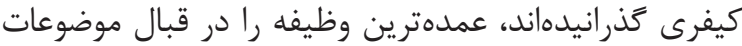

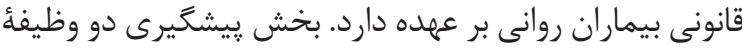

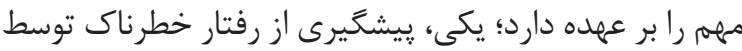

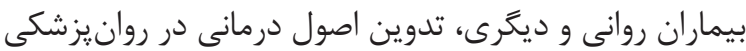

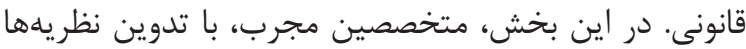

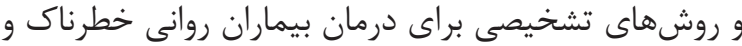

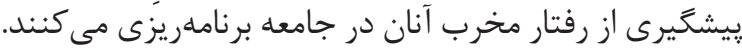

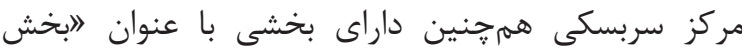

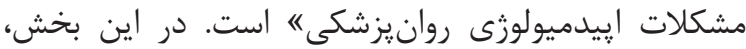

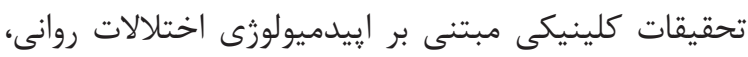

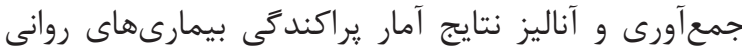

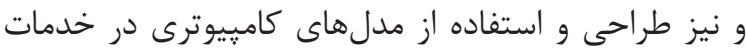

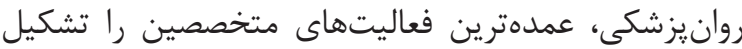
مى دهد.

روانيزشكى قانونى در سيستم قضايى روسيه با روشهاى

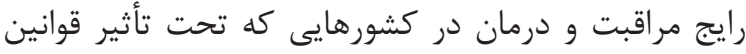

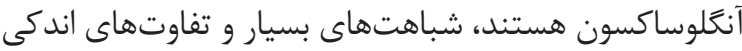

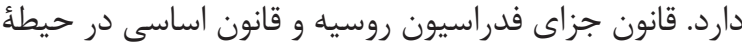

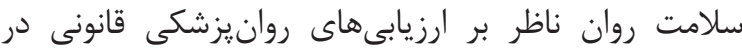

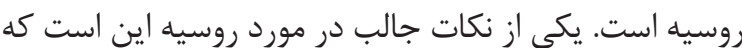

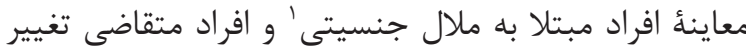

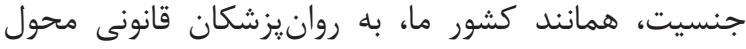

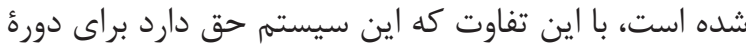

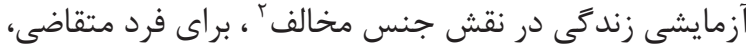

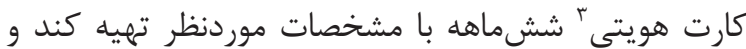

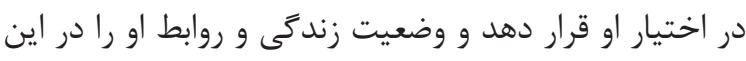

دانش روانيزشكى براى حمايت و درمان بيمارانى كه نياز به

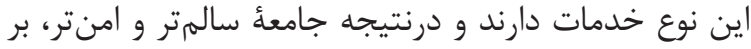

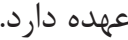

\section{انواع خدمات روانيزشكى قانونى}

در برخى كشورها (مثلا آلمان، روسيه، سوئد، انگلستان

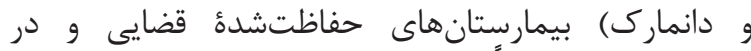

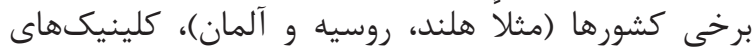

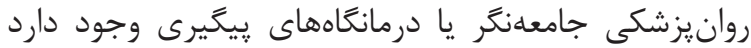

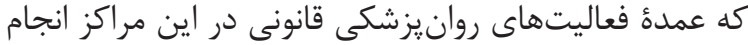

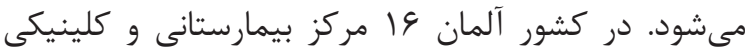

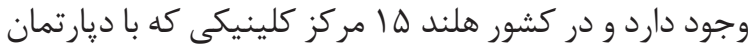
روانيزشكى قانونى مرتبط هستند. ازنظر نوع فعاليت، اقدامات

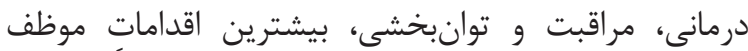

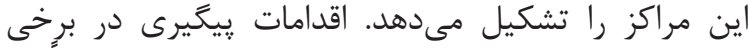

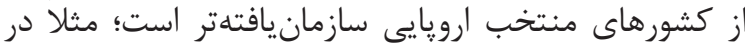

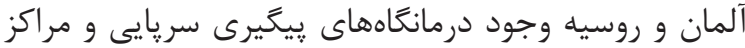

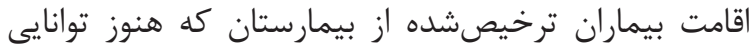

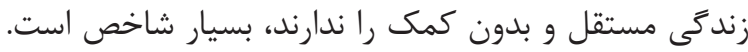

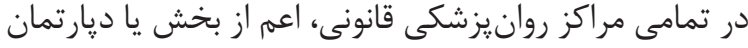

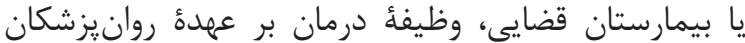

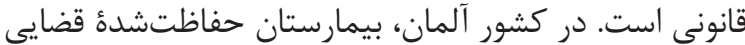
Haina نفر واقع شده است) و وجود بيمارستانهاى اقمارى (ازجمله

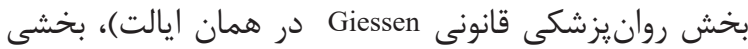

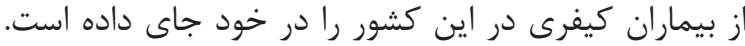

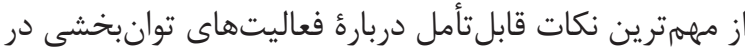

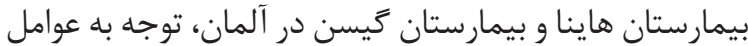

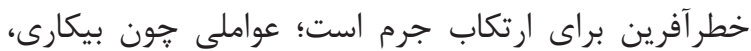

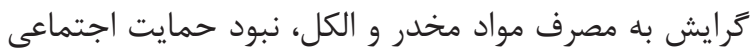

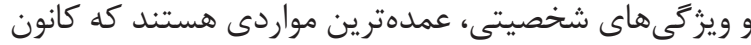

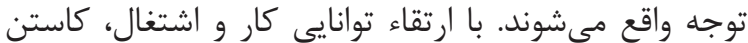

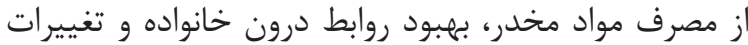

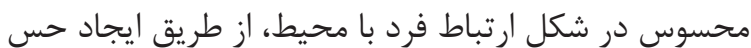

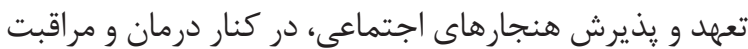

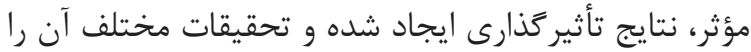

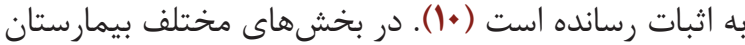

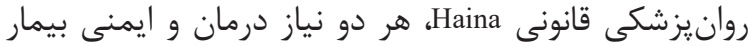

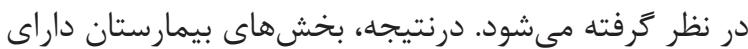

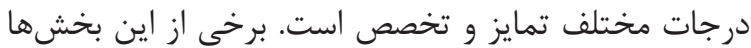

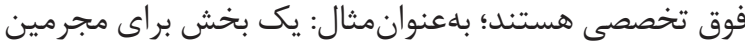

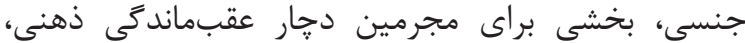

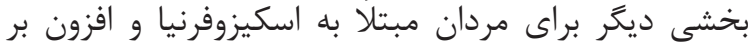

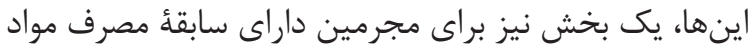

مخدر.

كشور دانمارك داراى يك بيمارستان كاملاً حفاظتشده 


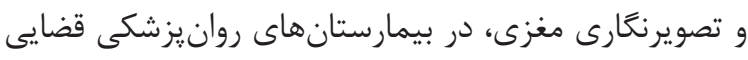

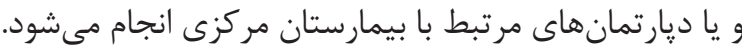

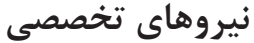

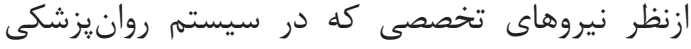
قانونى در كشورهاى منتخب ارويايى فعاليت مئى كنند، حضور

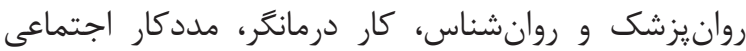

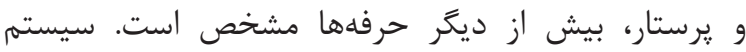

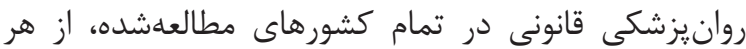

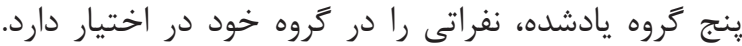

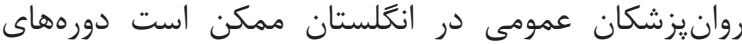

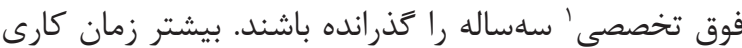

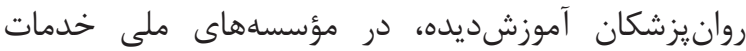

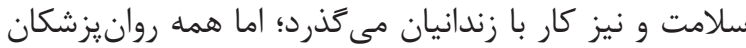

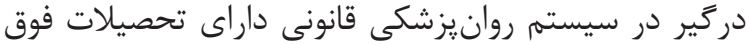

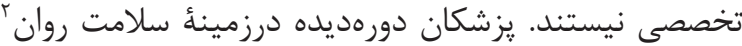

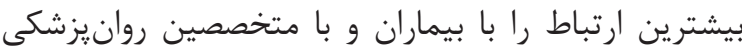

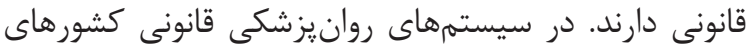

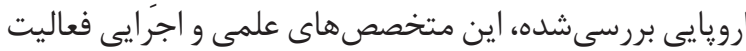

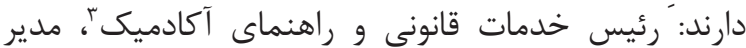

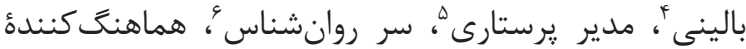

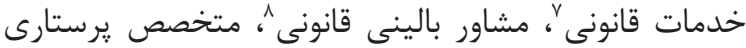

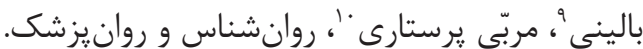

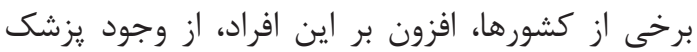

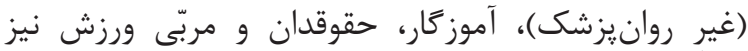

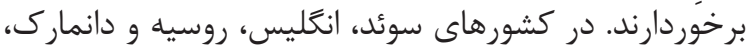

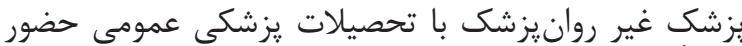

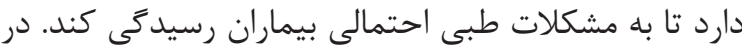

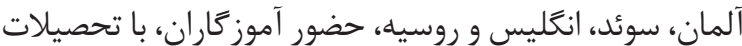

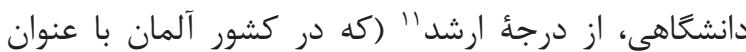

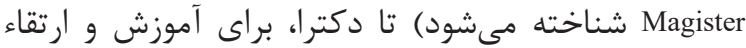

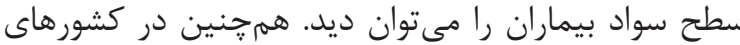

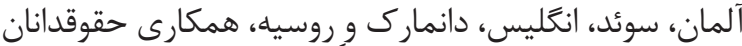

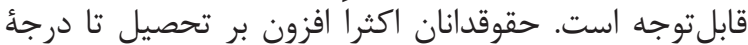

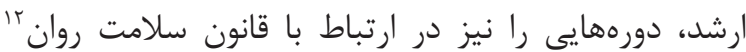

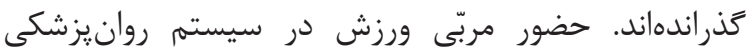

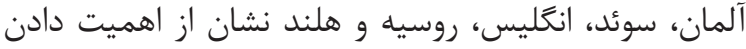

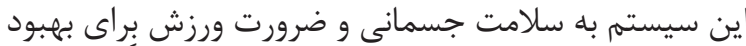

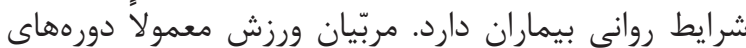

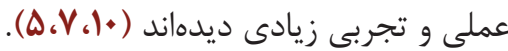

با توجه به تفاوت حوزههاى فعاليت روانيزشكى قارئ قانونى

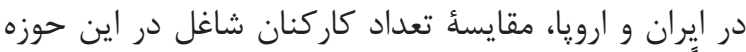

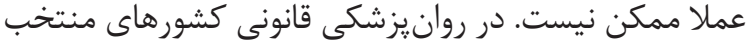

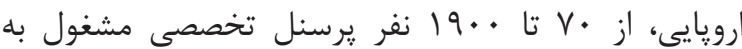
كار هستند و اين تعداد شامل تمامى نفرات يادشده، اعم از تازئ
مدت تحت نظر بخيرد. موضوعى كه به نظر مئرسد با با يافتن

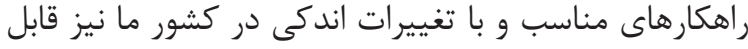

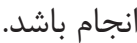

ساختار خدمات بهداشت روان كيفرى در سوئد در سال

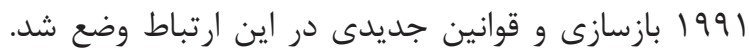

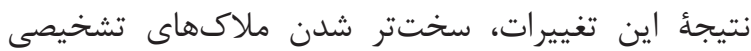

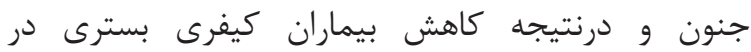

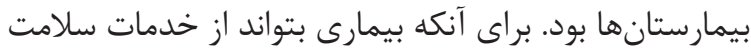

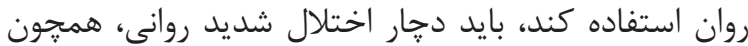
سايكوز و يا يكى از انواع قطعى اختلال شخصيت باديد باشد.

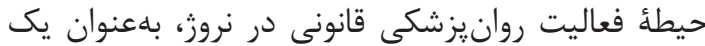

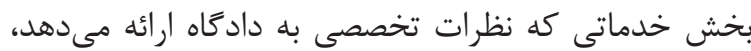

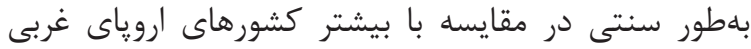

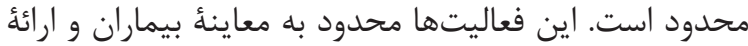

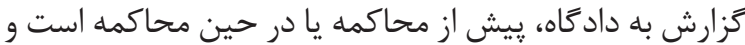

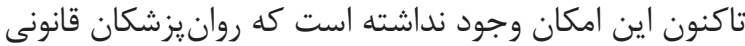

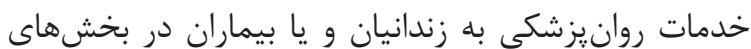

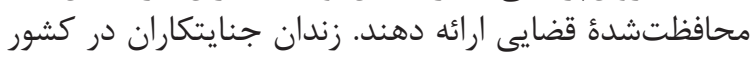

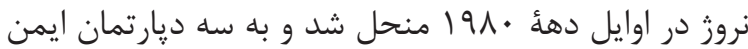

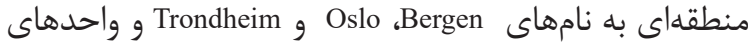

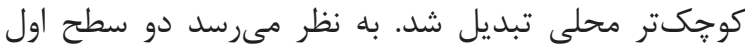

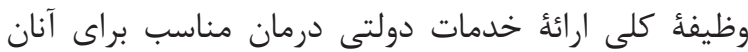

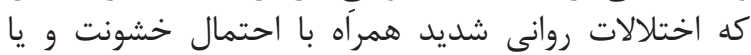

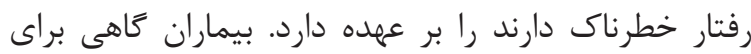

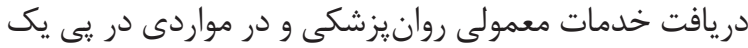

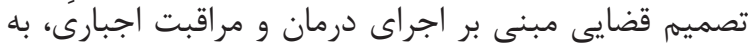

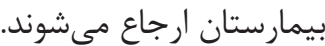

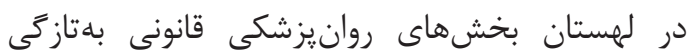

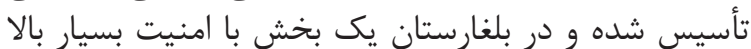

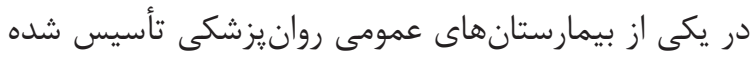

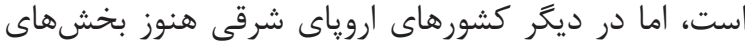

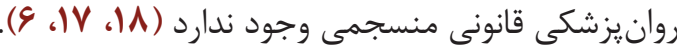

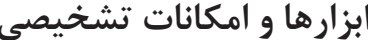

امكانات تشخيصى موجود در روانيزشكى قانونى كشور

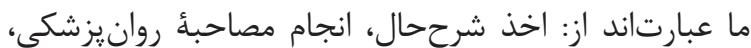
مطالعهُ يرونده قضايى و انجام اقدامات إنات ياراكلينيك موردنياز،

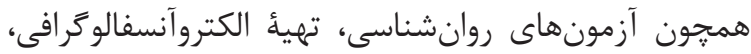

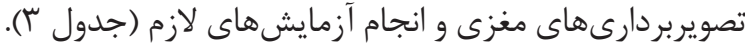

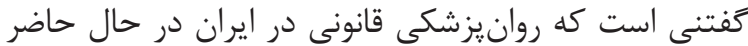

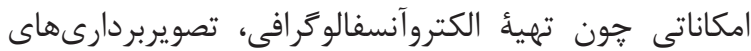

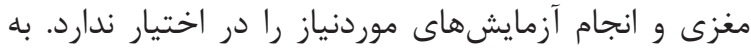

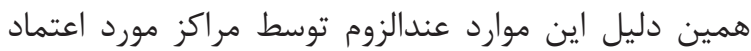

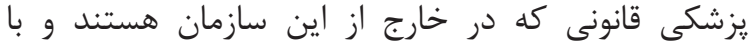

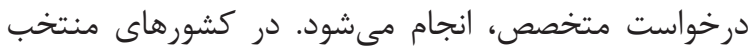

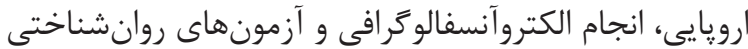




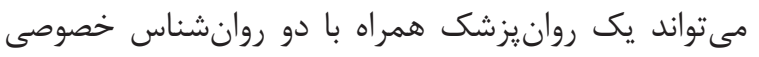

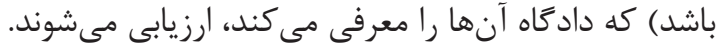

\section{كزارشهاى روانيزشكى قانونى}

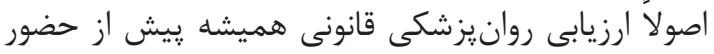

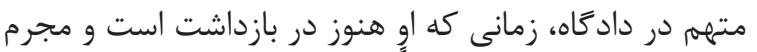

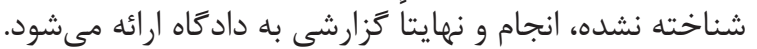

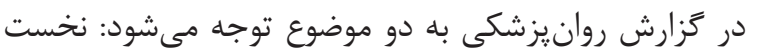

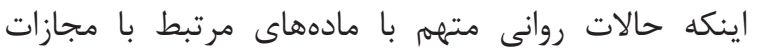

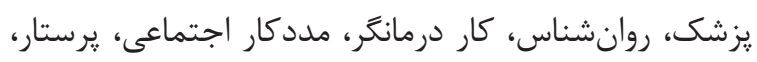

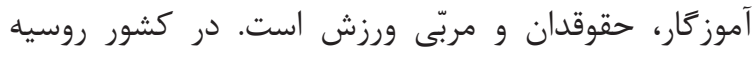

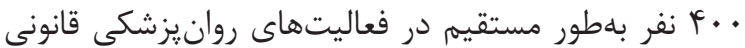

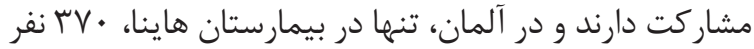

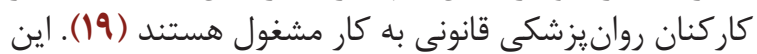

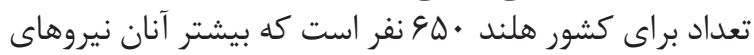

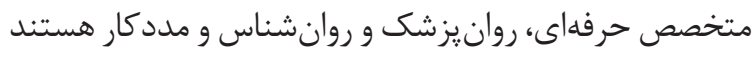

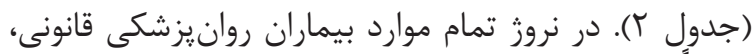

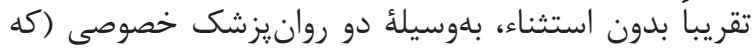

جدول شمارهُ ب. امكانات تشخيصى در مراكز روانيزشكى قانونى ايران و ارويا

\begin{tabular}{|c|c|c|c|c|c|c|}
\hline غير مستقيم رفتقيم يا & آزمايش هاى يزشكى & تصويرنتارى مغزى & الكترو آنسفالوكرافى & شناختى روان & مصاحبه و شرح حال & كشور \\
\hline+ & + & + & + & + & + & آلمان \\
\hline+ & + & + & + & + & + & سوئد \\
\hline+ & + & - & + & + & + & انغَليس \\
\hline+ & + & + & + & + & + & روسيه \\
\hline+ & + & + & + & + & + & دانمارى \\
\hline+ & - & - & - & + & + & نروز \\
\hline+ & + & - & + & + & + & هلند \\
\hline- & - & - & - & + & + & ايران \\
\hline
\end{tabular}

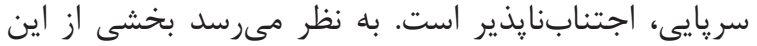

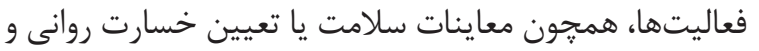

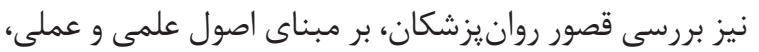

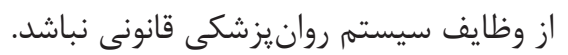

\section{آموزش در روانيزشكى قانونى}

در استانداردهاى آموزشى روانيزشكى قانونى در كشورهاى

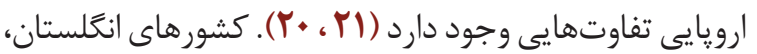

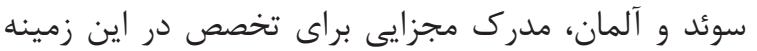

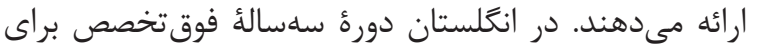

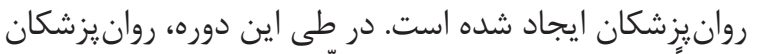

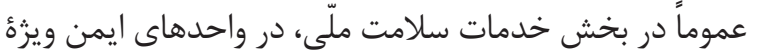

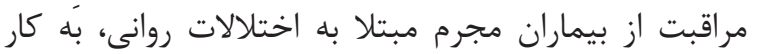

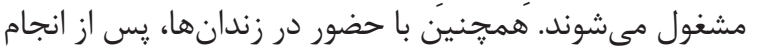

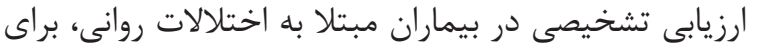

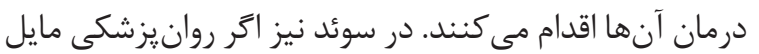

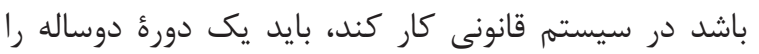

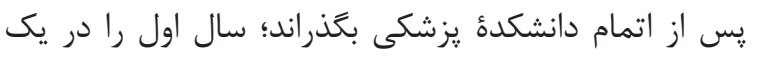

1. Subspecialty

2. Trained Mental Health

3. Head of Forensic Service \& Academic Lead

4. Clinical Director

5. Nurse Manager

6. Senior Psychologist

7. Forensic Service Coordinator

8. Clinical Legal Counsel

9. Clinical Nurse Specialist

10. Nurse Educator

11. Master

12. Mental Health Act

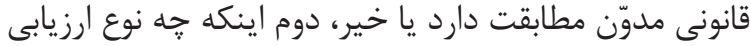

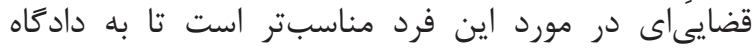
ينيشنهاد شود.

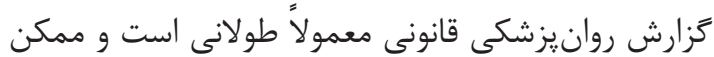

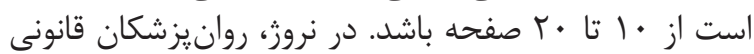

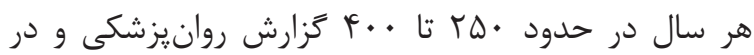

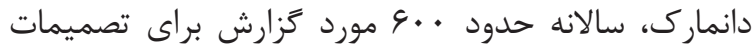

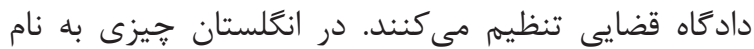

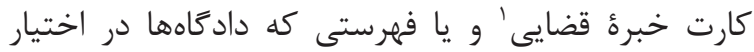

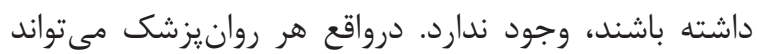

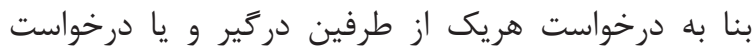

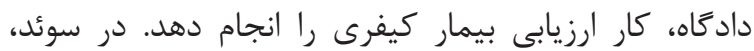

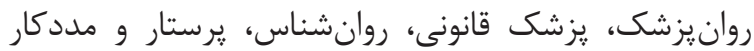

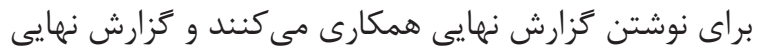

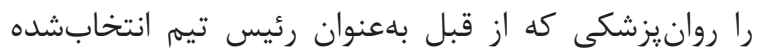

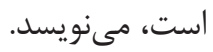

در سيستم روانيزشكى قانونى كشور ما تنها روانيزشكان

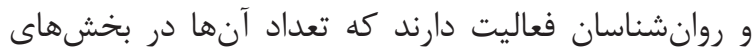

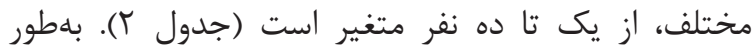

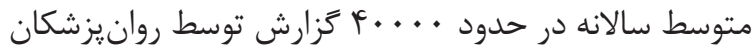

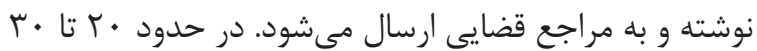

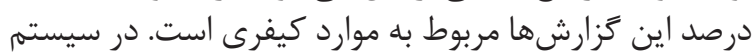

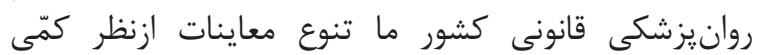

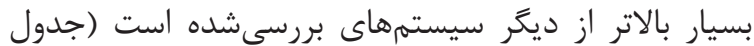

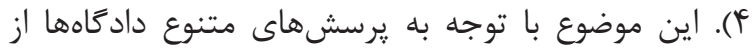
روانيزشكان قانونى و معطوف شدن آنان بان به انجام معاينات دادئ آنان 


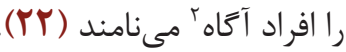

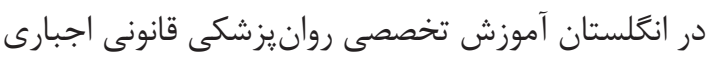

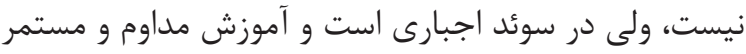

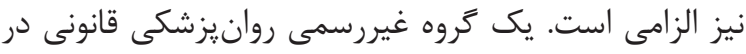

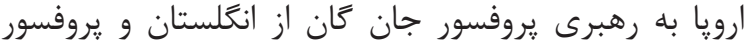

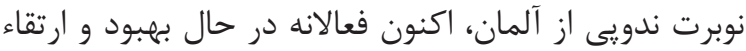
دورههاى تخصصى آموزشى در روانيز يزشكى قانونى آنى هستند

(Y)

\section{بحث و نتيجه تيرى}

تفاوت بسيار بارز فعاليتهاى روانيزشكى قانونى در در ايران

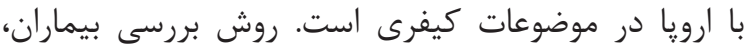

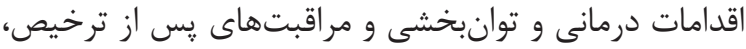

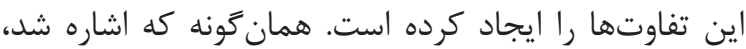

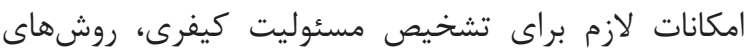

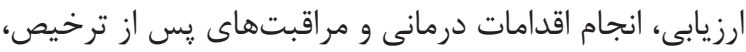

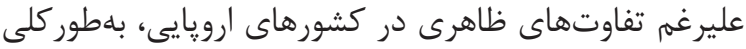

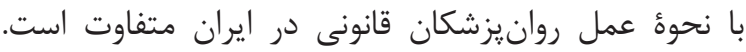

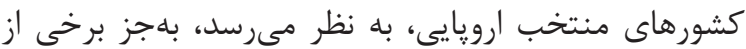

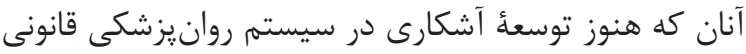

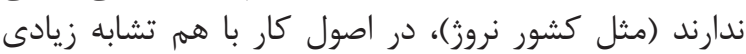

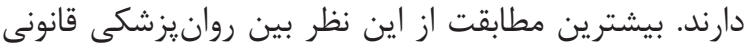

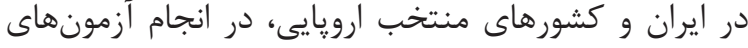

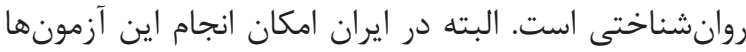

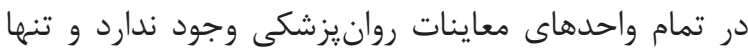

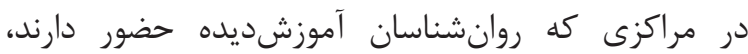

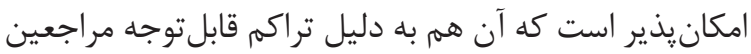

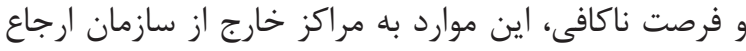

بخش روانيزشكى كه بيماران كيفرى را يذيرش و در درمان

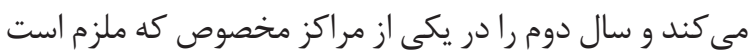

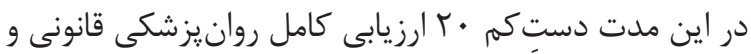

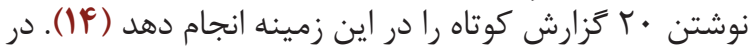

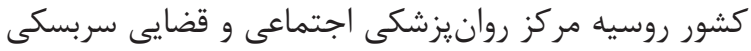

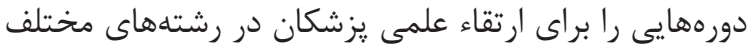

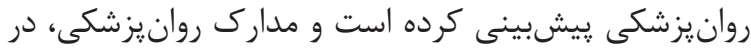

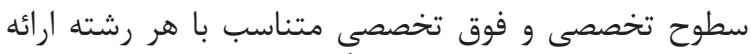

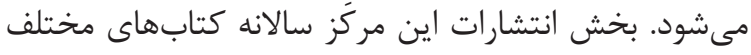

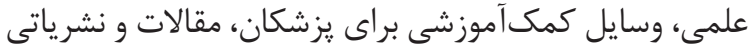

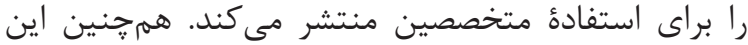

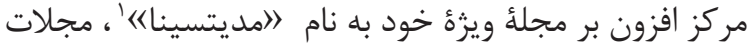
روانيزشكى روسيه را نيز منتشر مى كند بند.

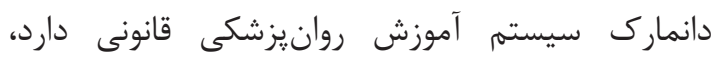

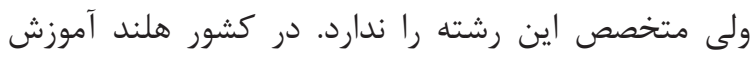

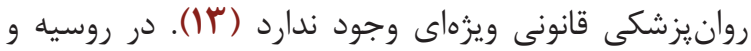

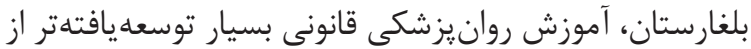

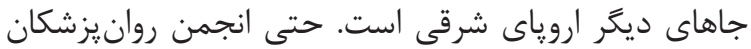

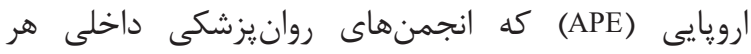

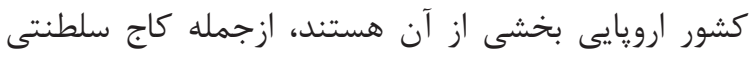

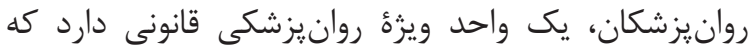

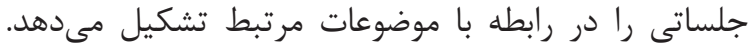

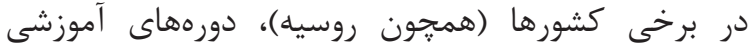

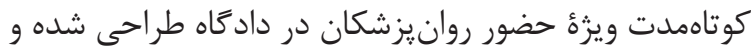

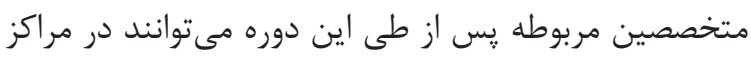

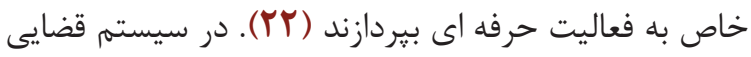
روسيه هر متخصص كارشناس و ازجمله روانيز يزشكان قانونى دئى

\section{جدول شماره F. تنوع معاينات انجامشده در مراكز روانيزشكى قانونى ايران و ارويا}

\begin{tabular}{|c|c|c|c|c|c|c|c|c|c|c|c|c|c|c|c|}
\hline 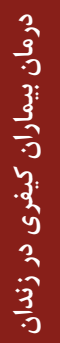 & 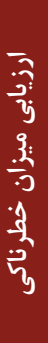 & $\begin{array}{c}3 \\
3 \\
3 \\
3 \\
3 \\
\frac{2}{3} \\
2 \\
2 \\
\frac{3}{3}\end{array}$ & 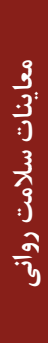 & $\begin{array}{l}3 \\
3 \\
3 \\
3 \\
3 \\
3 \\
3\end{array}$ & $\begin{array}{l}\frac{\bar{s}}{a} \\
\frac{y}{\alpha}\end{array}$ & 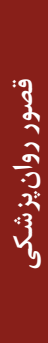 & $\begin{array}{l}\hat{3} \\
\hat{3} \\
\overrightarrow{3} \\
\hat{2} \\
\hat{3} \\
0\end{array}$ & $\begin{array}{l}3 \\
3 \\
3 \\
3 \\
3 \\
3 \\
3 \\
3 \\
3\end{array}$ & $\begin{array}{l}3 \\
3 \\
3 \\
3\end{array}$ & $\begin{array}{c}3 \\
3 \\
3 \\
3 \\
3 \\
0 \\
\frac{1}{3}\end{array}$ & 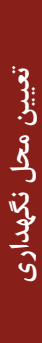 & & 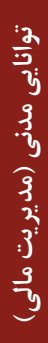 & 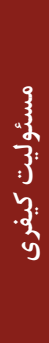 & 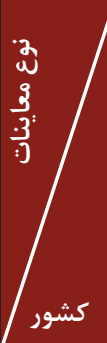 \\
\hline+ & + & + & - & - & - & - & - & + & - & - & + & - & + & + & آلمان \\
\hline+ & + & + & - & - & - & - & - & + & - & - & + & - & + & + & سوئد \\
\hline+ & + & + & - & - & - & - & - & + & - & - & - & - & + & + & انَحليس \\
\hline+ & + & + & - & + & - & - & + & + & - & - & + & + & + & + & روسيه \\
\hline+ & + & + & - & - & - & - & + & + & - & - & + & - & + & + & دانمارى \\
\hline+ & + & + & - & - & - & - & + & + & - & - & - & - & + & + & نروز \\
\hline+ & + & + & - & - & - & - & + & + & - & - & - & - & + & + & هلند \\
\hline- & + & - & + & + & + & + & - & + & + & + & + & + & + & + & ايران \\
\hline
\end{tabular}


كاردرمانى و توانبخشى، از طريق مشاركت دادن بيماران

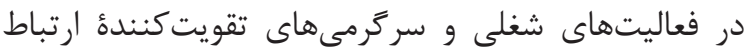

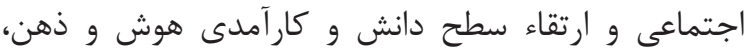

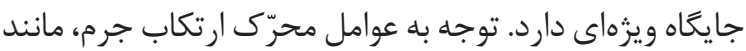

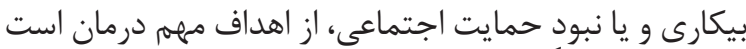

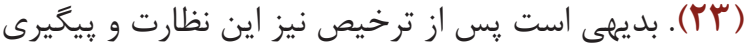

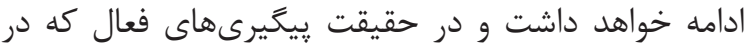

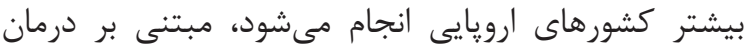

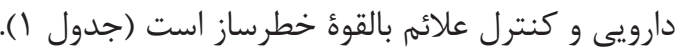
به ارزيابى خطرناك بودن كه يكى از مههمترين وظايف

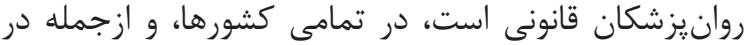

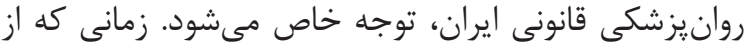

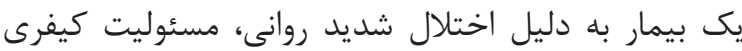

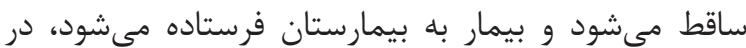

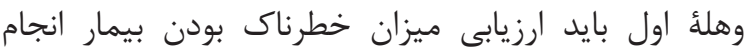

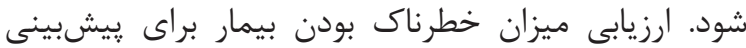

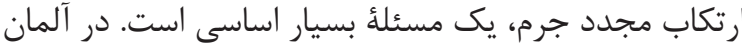

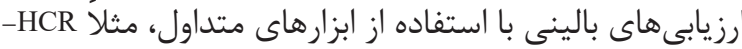

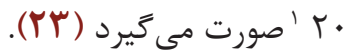

در كشور سوئد، به موضوع يزوهش نيز دروزئ درزمينأ

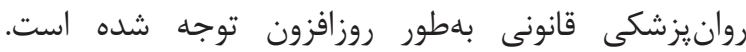

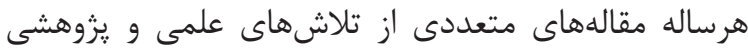

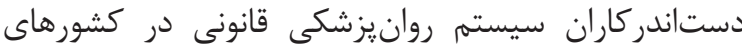

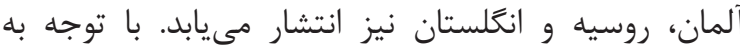

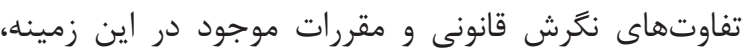

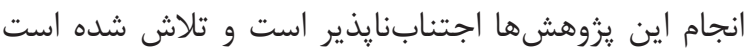

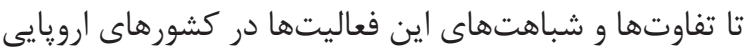

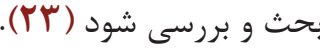

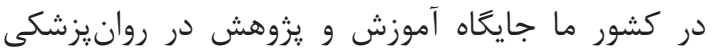

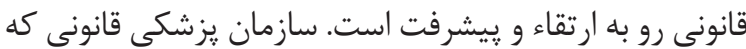

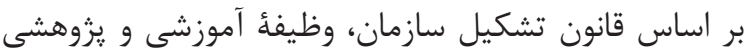

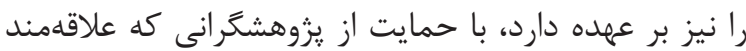

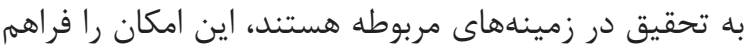

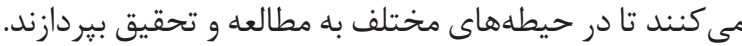

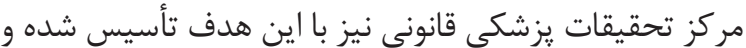

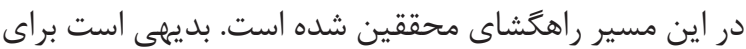

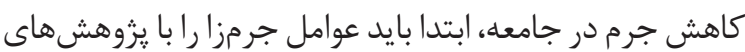

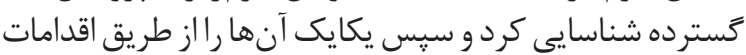

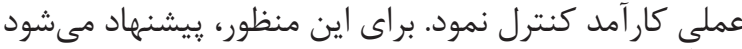

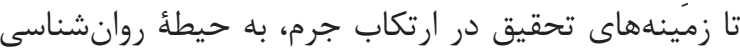

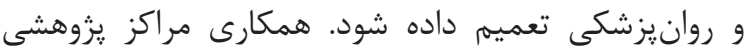

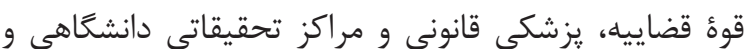

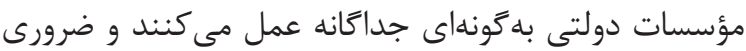

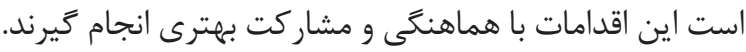

مىشوند. نكتهٔ قابلتوجه در مطالعهُ نحوهُ عملكرد تشخيصى

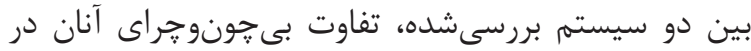

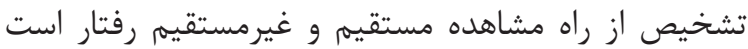

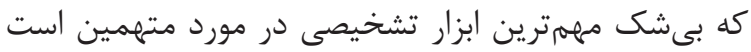

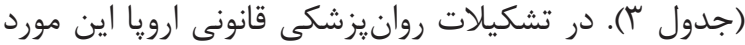

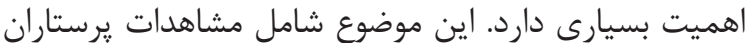

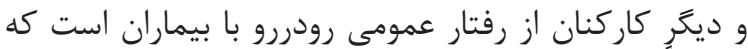

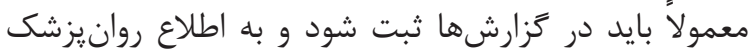

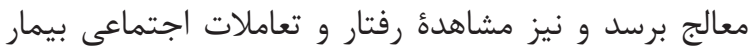

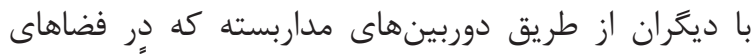

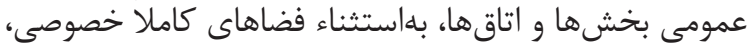

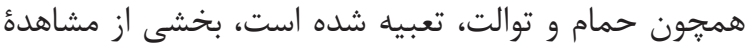

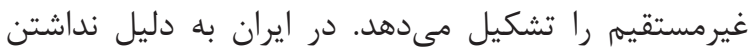

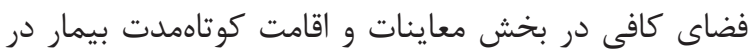

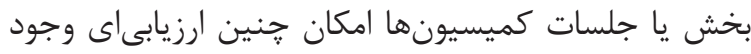

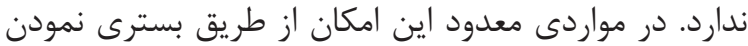

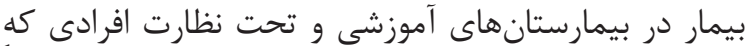

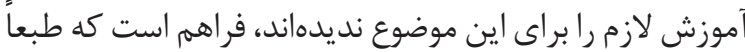

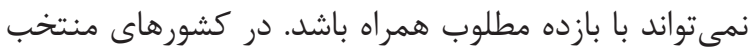

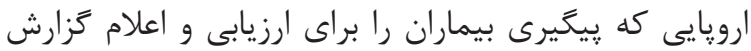

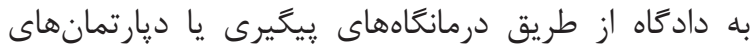

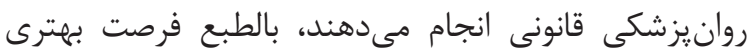
براى نظارت و تشخيص دقيقتر فراهم است دئ.

تنوع خدمات قابلارائه به بيماران كيفرى در سيستم إنمان

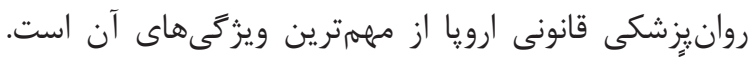

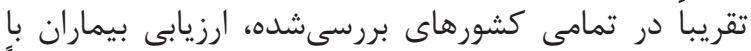

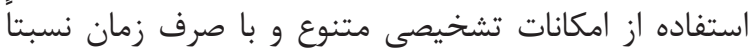

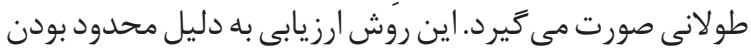

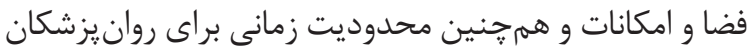

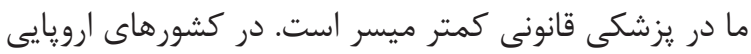

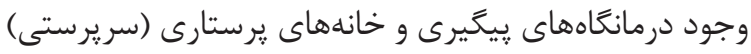

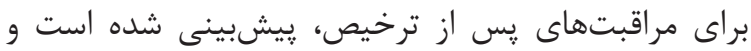

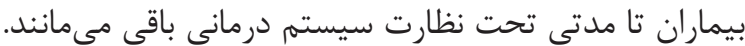

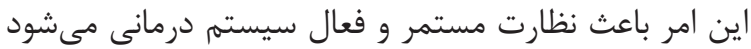

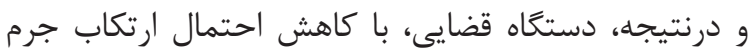

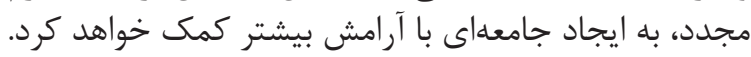

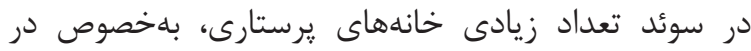

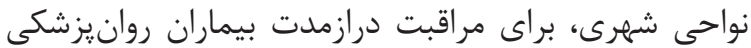

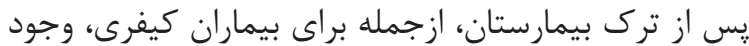

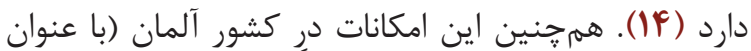

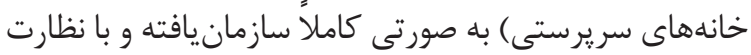
سازمان رفاه اجتماعى وجود دارد (جدول بل ().

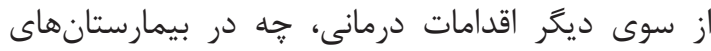

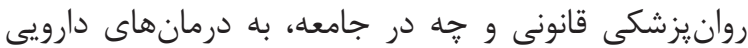

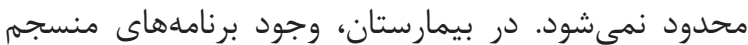




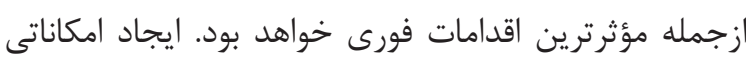

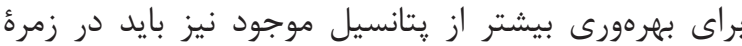

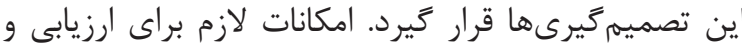

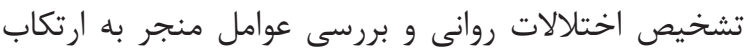

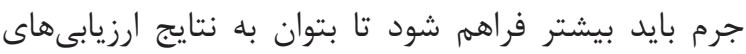

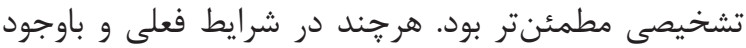

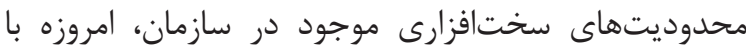

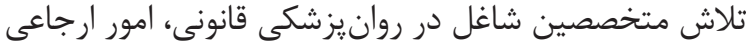

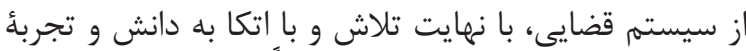

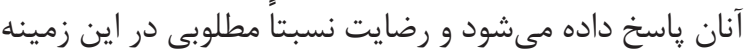

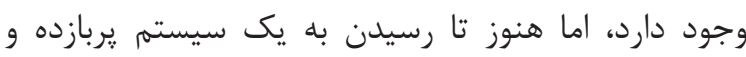

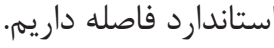

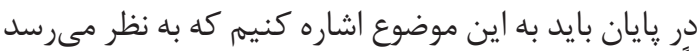

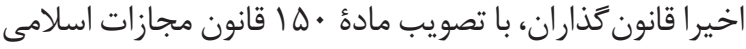

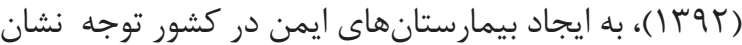

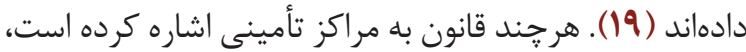

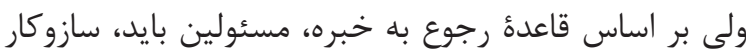

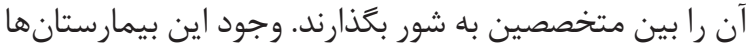

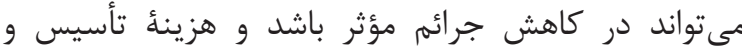

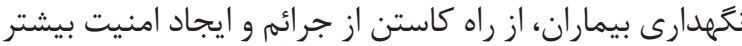

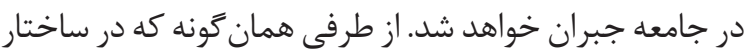

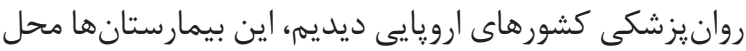

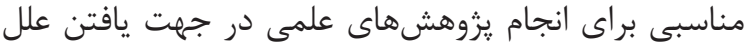

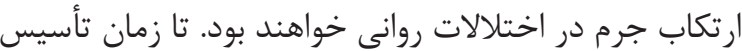

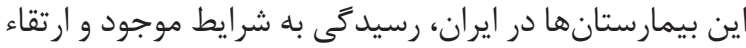

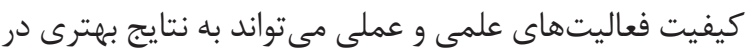

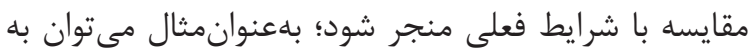

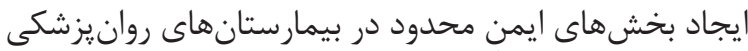

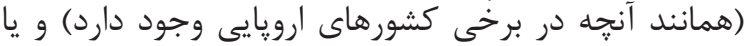

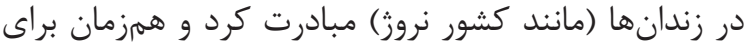

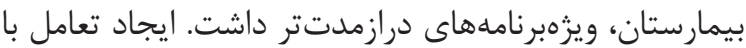

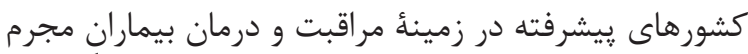

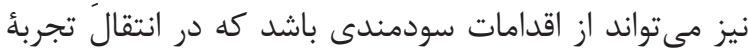

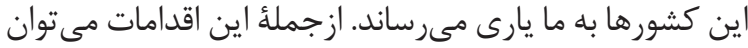

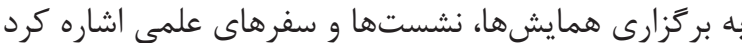

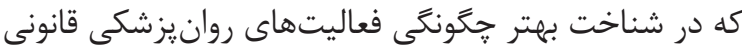
مى تواند بسيار كمك كننده باشد.

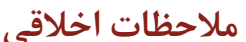

ملاحظات اخلاقى در نظر ترفتهشده براى انجام اين

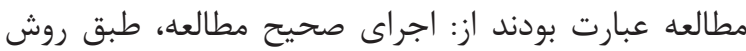

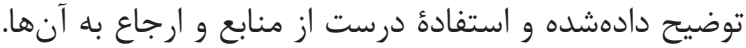

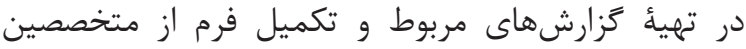

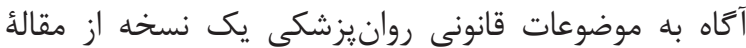

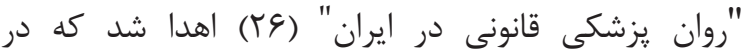

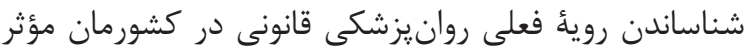
بود و به نظر مىرسد كه بازخورد مثبتى نيز داشته است داني.

1. Historical and clinical risk assessment

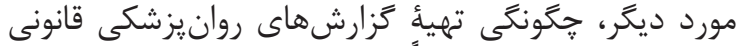

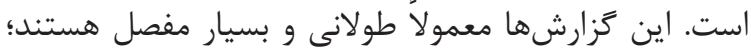

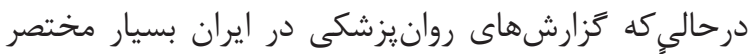

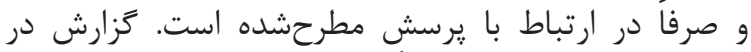

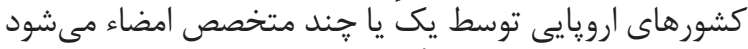

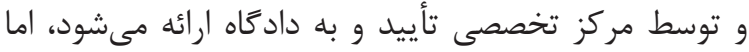

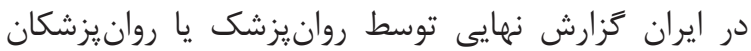

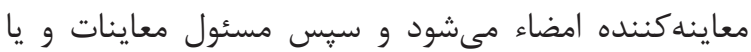

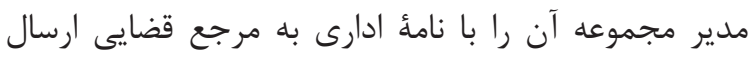

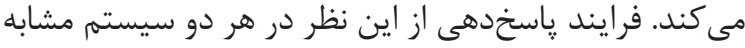
است.

با توجه به موارد كفتهشده در بالا، به نظر مىرسد شيؤ

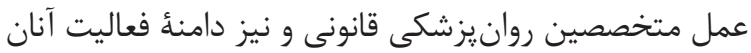

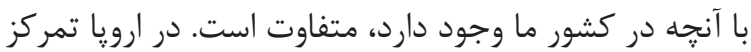

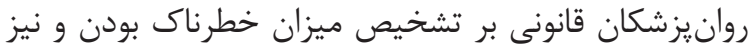

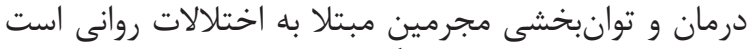

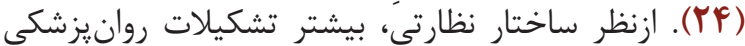

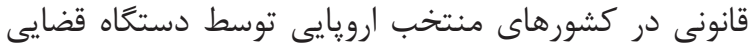

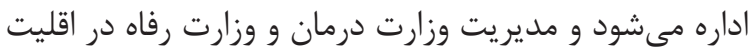

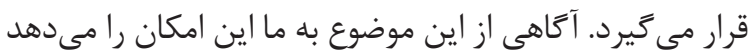

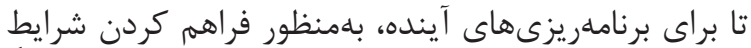

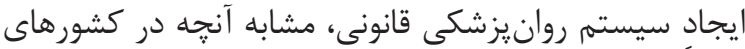

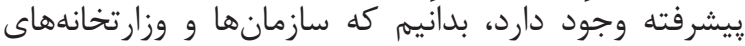

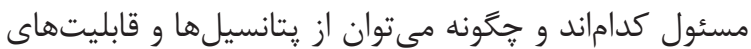

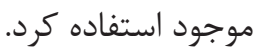
امروزه آنجه بيش از كذشته اهميت خود را نشان ميدهدهد،

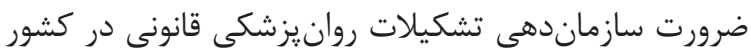

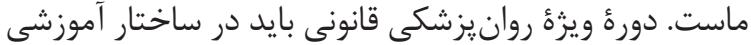

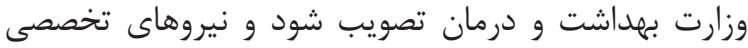

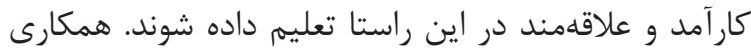

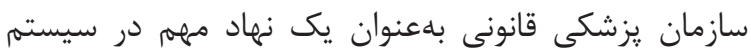

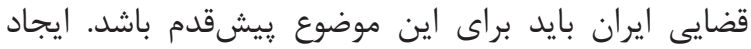

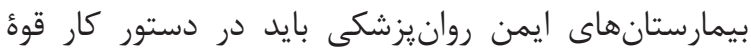

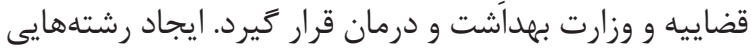

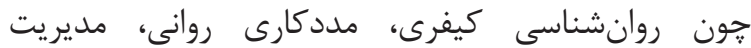

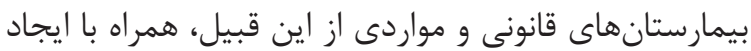

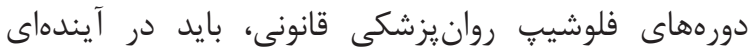

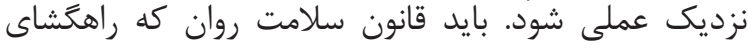

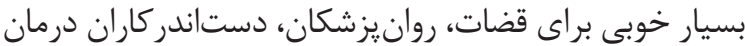

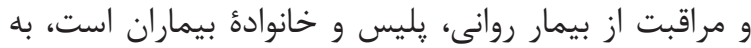

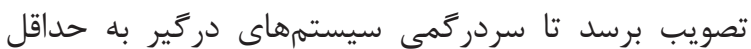

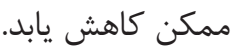

ارتقاء وضعيت موجود، سريعترين و امكانيذيرترين

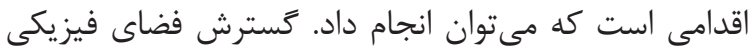

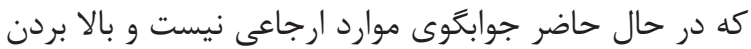

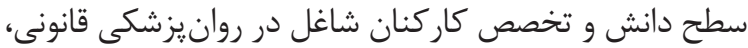




$$
\text { سياسگزارى }
$$

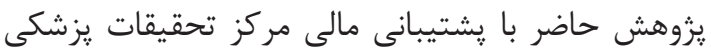

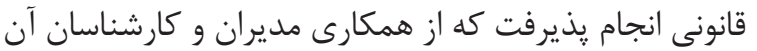

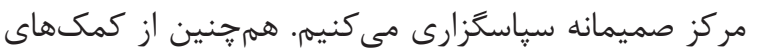

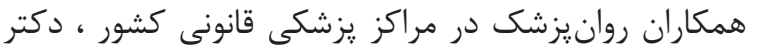

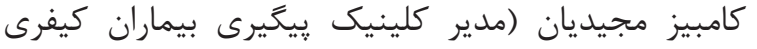

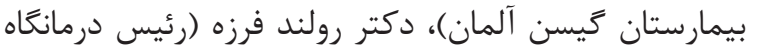

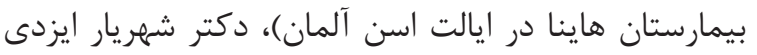

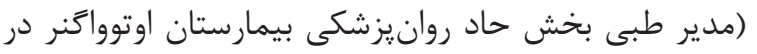

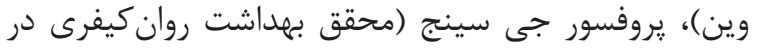

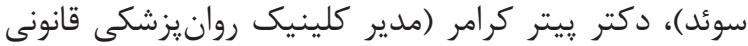

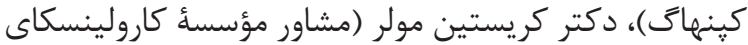

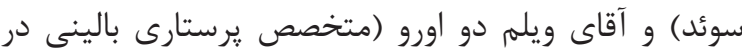

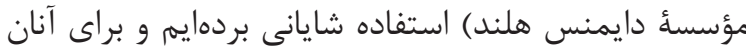

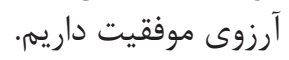

دحدوديتهاى اجرايى طرح عبارت بود از محدوديت

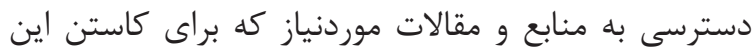

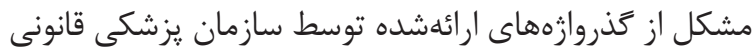

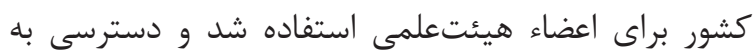

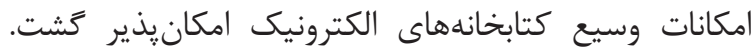

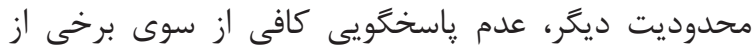

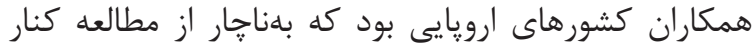

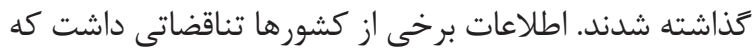

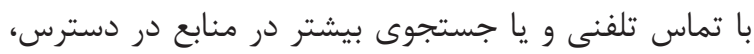

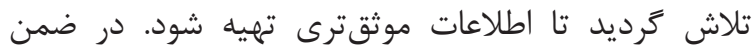

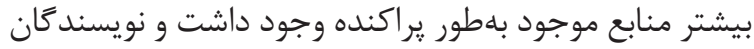
داده هاى اين منابع را در كنار يكديخر استفاده كردند.

\section{References}

1. Nicholls TL, Ogloff JR, Douglas KS. Assessing risk for violence among male and female civil psychiatric patients: the HCR-20, PCL: SV, and VSC. Behavioral Sciences \& the Law. 2004 Jan 1;22(1):127-58.

2. Relationship between levels of security and the CR-10score in hospital order treatment. Paper presented at the Annual Conference of the International Association of Forensic Mental Health Services, Munich, Germany. 2002

3. Nedopil N. The role of forensic psychiatry in mental health systems in Europe. Crim Behav Ment Health. 2009;19(4):224-34. https://doi. org/10.1002/cbm.719 PMID:19266477

4. Saberi SM, Mirsepassi Gholam Reza, Forensic psychiatry in Iran, Iran J Psychiatry Behav Sci, Volume 7, Number 1, Spring / Summer 2013, p. $1-3$

1. Saberi SM. Mohammadi Mohammadreza, A New Attitude on Forensic Psychiatry. 2nd ed. Taymoorzadeh Publications; 2013.[Persian].

2. The Document of Vision of the Islamic Republic of Iran in 1404, Research Department of Islamic Parliament, 2005 [Persian]

3. The Act of Establishment of Legal Medicine Organization. 1st ed. 2003.[Persian].
4. Sheikhazadi A, Saberi SM, Ghorbani M, Karimi MR, Meysamie AP, Marashi SM. A study of prevalence of faked psychotic symptoms in malingerers referred to Tehran Center of Forensic Psychiatry in 1389. Razi Journal of Medical Sciences. 2012;19(100):62-70.[Persian]

5. Gordon H, Lindqvist P. Forensic psychiatry in Europe, The Psychiatric Bulletin. Psychiatrist. 2007 Oct ;31(11):421-4.

6. Dontschev P, Gordon H. Forensic psychiatry in Bulgaria. Crim Behav Ment Health. 1997;7(2):141-51. https://doi.org/10.1002/cbm.159.

7. Priebe S, Badesconyi A, Fioritti A, Hansson L, Kilian R, Torres-Gonzales F et al. Reinstitutionalisation in mental health care: comparison of data on service provision from six European countries. BMJ. 2005 Jan;330(7483):123-6. https://doi.org/10.1136/bmj.38296.611215.AE PMID:15567803

8. Elias Abdalla-Filho; José Manoel Bertolote, Forensic psychiatric systems of the world, Rev. Bras. Psiquiatr. vol.28 suppl.2 São Paulo Oct. 2006

9. Olié JP, Lôo H. [Forensic psychiatry] [Article in French]. Bull Acad Natl Med. 2008 Feb;192(2):381-9. PMID:18819690 
10. Müller-Isberner R, Freese R, Jöckel D, Gonzalez Cabeza S. Forensic psychiatric assessment and treatment in Germany. Legal framework, recent developments, and current practice. Int $\mathrm{J}$ Law Psychiatry. 2000 Sep-Dec;23(5-6):467-80. https://doi.org/10.1016/S0160-2527(00)00056-X PMID:11143945

11. Konrad N. Redevelopment of forensic-psychiatric institutions in former East Germany. Int $\mathrm{J}$ Law Psychiatry. 2001 Jul-Oct;24(4-5):509-26. https://doi.org/10.1016/S0160-2527(01)00081-4 PMID:11521423

12. https://en.wikipedia.org/wiki/Forensic psychiatry, United Kingdom.

13. The Current Status of Norwegian Forensic Psychiatry. http://www.retspsykiatriskinteressegruppe. $\mathrm{dk} /$ Forensic-psychiatry-in-the-Nordic-countries

14. Boirot J., Forensic Psychiatry and Psychiatrists in Criminal Justice in Europe. A Comparative Study of England, Spain, Rumania, Sweden and France, Centre de Recherches Sociologiques sur le Droit et les Institutions Pénales, May 2014

15. Forensic Psychiatry in Norway. http://www. niuva.fi/nsfp/esitykset/17.\%2520Per\%2520Harald \%2520Bentsen_Forensic\%2520Psychiatry

16. Nedopil N. The role of forensic psychiatry in mental health systems in Europe. Crim Behav Ment Health. 2009;19(4):224-34. https://doi. org/10.1002/cbm.719 PMID:19266477

17. Ruchkin VV. The forensic psychiatric system of Russia. Int J Law Psychiatry. 2000 SepDec;23(5-6):555-65. https://doi.org/10.1016/ S0160-2527(00)00046-7 PMID:11143953

18. Ciszewski L, Sutula E. Psychiatric care for mentally disturbed perpetrators of criminal acts in Poland. Int J Law Psychiatry. 2000 SepDec;23(5-6):547-54.https://doi.org/10.1016/S01602527(00)00055-8 PMID:11143952

19. Saberi, Seyed Mehdi; Initiatives to Create a Protected Psychiatric Hospital in Iran; Look To the Clause 2 of Article 150 of The Islamic Penal Law, Scientific Journal of Forensic Medicine, 19(1,4), 409-416[Persian]
20. Gunn J, Nedopil N. European training in forensic psychiatry [editorial]. Crim Behav Ment Health. 2005;15(4):207-13. https://doi.org/10.1002/cbm.23 PMID:16575834

21. Gunn J. Management of the mentally abnormal offender: integrated or parallel. Proc R Soc Med. 1977 Dec;70(12):877-80. PMID:601067

22. Alexander O. Bukhanovsky MD DSC (Med.), (Rostov-On-Don, Russia) and Roman Gleyzer MD (Tacoma, WA), Forensic psychiatry in the Russian criminal justice system, American Academy of Psychiatry and the Law, September 2001. 26(3):14-16.

23. Gretenkord, L., Muller-Isberner, R., Ozokyay, K. \&Sommer, J. Validating the HCR-20

24. Relationship between levels of security and the CR-10score in hospital order treatment. Paper presented at the Annual Conference of the International Association of Forensic Mental Health Services, Munich, Germany. 2002

25. Nedopil N. The role of forensic psychiatry in mental health systems in Europe. Crim Behav Ment Health. 2009;19(4):224-34. https://doi. org/10.1002/cbm.719 PMID:19266477

26. Saberi Seyed Mehdi, Mirsepassi Gholam Reza, Forensic psychiatry in Iran, Iran J Psychiatry Behav Sci, Volume 7, Number 1, Spring / Summer 2013, p. $1-3$ 